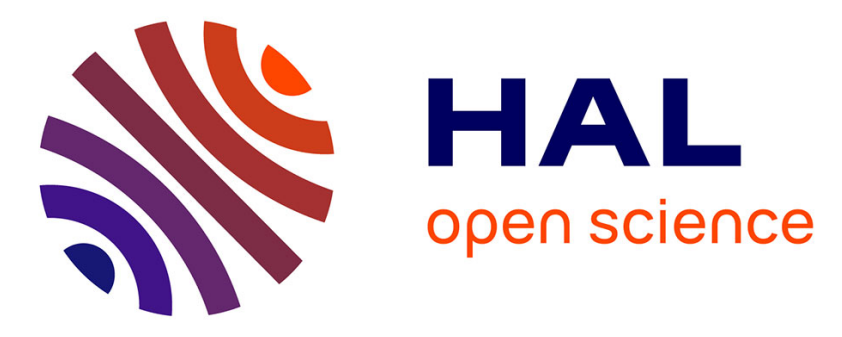

\title{
Triangulation of the human, chimpanzee and Neanderthal genome sequences identifies potentially compensated mutations
}

Guojie Zhang, Pei Zhang, Michael Krawczak, Edward V. Ball, Matthew Mort, Hildegard Kehrer-Sawatzki, David N. Cooper

\section{To cite this version:}

Guojie Zhang, Pei Zhang, Michael Krawczak, Edward V. Ball, Matthew Mort, et al.. Triangulation of the human, chimpanzee and Neanderthal genome sequences identifies potentially compensated mutations. Human Mutation, 2010, 31 (12), pp.1286. 10.1002/humu.21389 . hal-00591288

\section{HAL Id: hal-00591288 \\ https://hal.science/hal-00591288}

Submitted on 9 May 2011

HAL is a multi-disciplinary open access archive for the deposit and dissemination of scientific research documents, whether they are published or not. The documents may come from teaching and research institutions in France or abroad, or from public or private research centers.
L'archive ouverte pluridisciplinaire HAL, est destinée au dépôt et à la diffusion de documents scientifiques de niveau recherche, publiés ou non, émanant des établissements d'enseignement et de recherche français ou étrangers, des laboratoires publics ou privés. 
Human Mutation

WILEY

\section{Triangulation of the human, chimpanzee and Neanderthal genome sequences identifies potentially compensated mutations}

\begin{tabular}{|c|c|}
\hline Journal: & Human Mutation \\
\hline Manuscript ID: & humu-2010-0442.R1 \\
\hline Wiley - Manuscript type: & Rapid Communication \\
\hline $\begin{array}{r}\text { Date Submitted by the } \\
\text { Author: }\end{array}$ & 06-Oct-2010 \\
\hline Complete List of Authors: & $\begin{array}{l}\text { Zhang, Guojie; Beijing Genomics Institute at Shenzhen, } \\
\text { Bioinformatics Department } \\
\text { Zhang, Pei; Beijing Genomics Institute at Shenzhen, Bioinformatics } \\
\text { Department } \\
\text { Krawczak, Michael; Christian-Albrechts-Universität zu Kiel, Institut } \\
\text { für Medizinische Informatik und Statistik } \\
\text { Ball, Edward; Cardiff University, Institute of Medical Genetics, } \\
\text { College of Medicine } \\
\text { Mort, Matthew; Cardiff University, Institute of Medical Genetics, } \\
\text { College of Medicine } \\
\text { Kehrer-Sawatzki, Hildegard; University of Ulm } \\
\text { Cooper, David; Cardiff University, Institute of Medical Genetics, } \\
\text { College of Medicine }\end{array}$ \\
\hline Key Words: & $\begin{array}{l}\text { Neanderthal genome, HGMD, potentially compensated mutations, } \\
\text { complex disease susceptibility }\end{array}$ \\
\hline
\end{tabular}

\section{SCHOLARONE ${ }^{\text {m }}$ Manuscripts}


Humu-2010-0442

Rapid Communication

Supporting Information for this preprint is available from the

Human Mutation editorial office upon request (humu@wiley.com)

\section{Triangulation of the human, chimpanzee and Neanderthal genome sequences identifies potentially compensated mutations}

Guojie Zhang ${ }^{1 *}$, Zhang Pei ${ }^{1}$, Michael Krawczak ${ }^{2}$, Edward V. Ball ${ }^{3}$, Matthew Mort ${ }^{3}$, Hildegard Kehrer-Sawatzki ${ }^{4}$, David N. Cooper ${ }^{3 *}$

${ }^{1}$ Bioinformatics Department, Beijing Genomics Institute at Shenzhen, Shenzhen 518083, China.

${ }^{2}$ Institut für Medizinische Informatik und Statistik, Christian-Albrechts-Universität zu Kiel, Arnold-Heller-Straße 3, Haus 31, 24113 Kiel, Germany.

${ }^{3}$ Institute of Medical Genetics, School of Medicine, Cardiff University, Heath Park, Cardiff CF14 4XN, UK.

${ }^{4}$ Institut für Humangenetik, Universität Ulm, Albert-Einstein-Allee 11, 89081 Ulm, Germany.

*Corresponding authors:

Guojie Zhang. Email: zhanggj@genomics.org.cn 
Tel: +86-0755-25273794 Fax: +86-0755-25273114

David N. Cooper. Email: cooperdn@ cardiff.ac.uk

Tel:+44-2920-744062 Fax: +44-2920-746551 


\begin{abstract}
Triangulation of the human, chimpanzee and Neanderthal genome sequences with respect to 44,348 disease-causing or disease-associated missense mutations and 1,712 putative regulatory mutations listed in the Human Gene Mutation Database was employed to identify genetic variants that are apparently pathogenic in humans but which may represent a 'compensated' wild-type state in at least one of the other two species. Of 122 such 'potentially compensated mutations' (PCMs) identified, 88 were deemed 'ancestral' on the basis that the reported wild-type Neanderthal nucleotide was identical to that of the chimpanzee. Another 33 PCMs were deemed to be 'derived' in that the Neanderthal wild-type nucleotide matched the human but not the chimpanzee wild-type. For the remaining PCM, all three wild-type states were found to differ. Whereas a derived PCM would require compensation only in chimpanzee, ancestral PCMs are useful as a means to identify sites of possible adaptive differences between modern humans on the one hand, and Neanderthals and chimpanzees on the other. Ancestral PCMs considered to be disease-causing in humans were identified in two Neanderthal genes (DUOX2, $M A M L D 1)$. Since the underlying mutations are known to give rise to recessive conditions in human, it is possible that they may also have been of pathological significance in Neanderthals.
\end{abstract}

KEY WORDS: Human; chimpanzee; Neanderthal; genome sequence; potentially compensated mutations; complex disease susceptibility 


\section{Introduction}

The comparison of the human genome sequence with that of our closest living relative, the chimpanzee, has given us a broad overview of the spectrum of genetic changes that accompanied human evolution over the last 5-6 Myrs since the divergence of the two species [Kehrer-Sawatzki and Cooper, 2007; Marques-Bonet et al., 2009]. It is clear that both gross karyotypic rearrangements and submicroscopic variation (involving deletions, duplications and inversions) have made a significant contribution to the structural divergence of the two genomes, which is at least three-fold greater than the sequence divergence due to nucleotide substitution. This notwithstanding, detailed evaluation of the latter has served to identify many genes that exhibit signatures of selective sweeps (i.e. periods of intense positive selection) and which may therefore have been involved in the development of human lineage-specific traits [Bakewell et al., 2007; Enard et al., 2010]. Since signals of selective sweeps are likely to coincide with genetic variants that exert a significant effect on phenotypic variation in modern humans, they could, at least in principle, also impact upon susceptibility to common disease [Di Rienzo and Hudson, 2005; Nielsen et al., 2007]. In support of this assertion, there is a tendency for genes that have been positively selected during mammalian evolution to be disproportionately associated with human inherited disease [Clark et al., 2003; Vamathevan et al., 2008; Corona et al., 2010].

Positively selected mutations may include 'compensated' mutations, i.e. variants that were (actually or potentially) deleterious for a certain period of time, but which persisted long enough in a given population or species to have become positively selected upon the 
introduction of a 'compensatory' mutation [Di Rienzo and Hudson, 2005; Corona et al., 2010]. Suriano et al. (2007) provided a good example of the interplay of compensated and compensating mutations in the context of a human disease. The human and chimpanzee OTC amino acid sequences differ at only two positions, 125 and 135, where Thr was found to represent both ancestral states. Replacements Thr135Ala and Thr125Met have occurred respectively in the human and chimpanzee lineages since their divergence from their common ancestor. However, whilst the wild-type combination of Met125 and Thr135 in chimpanzee gives rise to an apparently normal phenotype, recurrence of Met125 against the background of the human-specific Ala135 residue results in a clinical phenotype (human neonatal hyperammonemia). Suriano et al. (2007) demonstrated in vitro that human OTC bearing Met125 is inactive whereas the chimpanzee version with Met at the same position possesses an enzymatic activity comparable to wild-type human OTC. The presence of Thr135 in chimpanzee therefore rescues the otherwise deleterious effect of Met125 through intra-locus compensation.

The chimpanzee genome has been found to harbour several examples of such potentially compensated mutations (PCMs), formally defined as human disease-causing or disease-associated missense mutations for which the substituting amino acid is identical to the wild-type amino acid residue at the orthologous position in chimpanzee [Mikkelsen et al., 2005; Azevedo et al., 2006]. The absence of strongly deleterious consequences of a specific PCM in chimpanzee would be explicable either by virtue of the very different (simian) environment or by dint of hitherto unidentified variants ('compensatory mutations') in the chimpanzee genome 
that could have served to epistatically buffer the PCM [Azevedo et al., 2006]. It should be noted, however, that a PCM may only have become disadvantageous in the human lineage as a consequence of the acquisition of other lineage-specific genetic variants or due to changes in the human environment and/or lifestyle [Di Rienzo and Hudson, 2005; Corona et al., 2010]. In this case, it would not have been necessary for the chimpanzee PCM to be compensated for at any time, which is why the qualifier 'potentially' is important when PCMs are defined on the basis of current genetic and clinical data.

Although the chimpanzee is our closest living relative, our closest known relatives were the now extinct Neanderthals (Homo neanderthalensis) from whom modern humans diverged between 300,000 and 700,000 years ago [Noonan et al., 2006]. The Neanderthals finally disappeared from the fossil record 28,000 years ago [Mellars, 2004; Noonan, 2010], due to either climate change [Tzedakis et al., 2007] or competitive exclusion by anatomically modern humans [Banks et al., 2008]. Recently, a draft sequence (with 1.3-fold coverage) of the Neanderthal genome, comprising $>4$ billion nucleotides derived from three apparently unrelated individuals, became available [Green et al., 2010]. Sequence differences between Neanderthals and modern humans were identified that pinpointed genomic regions potentially affected by positive selection [Green et al., 2010]. Furthermore, comparison of the Neanderthal and human genome sequences revealed that Neanderthal genetic material is present at a low level (1-4\%) in those modern humans whose ancestors had probably migrated across Europe or Asia, but not in the genomes of individuals from two extant African populations studied [Green et al., 2010].

In this study, we have compared 3,202,190 nucleotide positions at which the Neanderthal 6 John Wiley \& Sons, Inc. 
genome differs from either the human or the chimpanzee genome, or both, with a collection of 46,060 disease-causing or disease-associated mutations listed in the Human Gene Mutation Database [HGMD; Stenson et al., 2009]. From this comparison, we identified 122 HGMD mutations that apparently correspond to the wild-type allele in the Neanderthal or chimpanzee genomes (Figure 1). These mutations were further analysed in an attempt to identify PCMs in the Neanderthal genome that might in turn indicate sites of adaptive difference between modern humans and Neanderthals.

\section{Methods}

\section{HGMD dataset}

A total of 46,060 disease-causing or disease-associated mutations were obtained from the Human Gene Mutation Database [Stenson et al., 2009; http://www.hgmd.org] as of 13 May 2010. These data comprised 44,348 missense mutations from within the coding regions of 2,628 genes, and 1,712 single base-pair substitutions from within the regulatory regions (5' and 3 ' untranslated/flanking regions) of 807 genes. Some 42,595 of the mutations were disease-causing (DM; 41,960 missense and 635 regulatory) whereas 3,465 represented disease-associated or functional polymorphisms (2,388 missense and 1,077 regulatory) (Table 1$)$. The latter were further ascribed to three distinct sub-categories: (i) disease-associated polymorphisms (DP), comprising variants reported to be in statistically significant association with a particular human disease state $(\mathrm{p}<0.05)$ but lacking experimental evidence of functionality e.g. from expression studies, (ii) disease-associated polymorphisms with experimental evidence of functionality 
(DFP) such as, for example, altered in vitro gene expression or protein function (iii) functional polymorphisms (FP) that have been shown in vitro or in vivo to affect the structure, function or expression of the gene or gene product, but for which no statistically significant disease association has yet been reported (see http://www.hgmd.cf.ac.uk/docs/poly.html for further information).

\section{Search for potentially compensated mutations (PCMs)}

Sequence data on a total of 3,202,190 nucleotide positions at which the Neanderthal genome differs from either the human or chimpanzee genome (or both) were downloaded from the European Bioinformatics Institute website (ftp://ftp.ebi.ac.uk/). These positions were originally identified through mismatches between the human and chimpanzee genomes, followed by an alignment of Neanderthal sequence reads against both other species [Green et al., 2010]. At a total of $2,813,802$ positions $(87.9 \%)$, human and Neanderthal exhibited the same nucleotide, so that the human-chimpanzee mismatch must have arisen before the divergence of modern humans and Neanderthals (termed a 'derived' or 'D' state in the Neanderthal). A total of 38,228 positions (1.2\%) displayed the same nucleotide in both Neanderthal and chimpanzee, suggesting that the respective substitutions were human-specific ('ancestral' or 'A' state in the Neanderthal). The remaining $\sim 350,160$ positions, which display different nucleotides in modern humans, Neanderthals and chimpanzees, were termed 'undefined' ('N' state). Since most of the $\mathrm{N}$ state positions overlapped with low quality Neanderthal sequencing reads, they were not considered further in this analysis. Among the remaining 2,852,030 positions, constituting the 
'Neanderthal nucleotide substitution dataset', we identified 122 sites for which the apparent wild-type nucleotide in either Neanderthal or chimpanzee was logged in HGMD as disease-causing or disease-associated in humans (Figure 1).

\section{Gene Ontology (GO) enrichment analysis}

A Gene Ontology (GO) enrichment analysis of PCM-containing genes was performed using the Cytoscape software (http://www.cytoscape.org; version 2.5.2) with Bingo plugin (http://www.psb.ugent.be/cbd/papers/BiNGO/, version 2.3). The statistical significance of particular GO terms was assessed using a hypergeometric distribution, adjusted for multiple testing by consideration of the Benjamini-Hochberg False Discovery Rate [Benjamini and Hochberg, 1995].

\section{Calculation of $F_{S T}$}

The fixation index, $\mathrm{F}_{\mathrm{ST}}$, measures the proportion of genetic diversity in a sub-divided population that is due to allele frequency differences between sub-populations. Pair-wise $F_{S T}$ values may also be used as a measure of genetic distance between populations. Here, allele frequencies of polymorphic ancestral PCMs in selected populations were obtained from HapMap (http://hapmap.ncbi.nlm.nih.gov/) and pair-wise $F_{S T}$ values were estimated for each polymorphism using the small sample estimate proposed by Weir and Hill [2002]. The significance of individual $\mathrm{F}_{\mathrm{ST}}$ values was then assessed by reference to the empirical distribution of $\mathrm{F}_{\mathrm{ST}}$ among all SNPs in HapMap. 


\section{Protein structure modeling and ligand-protein binding site prediction}

Protein structure modeling was carried out for three different versions of the MAMLD1 protein, jointly defined by a PCM (V505A) and a second, apparently non-pathological human-chimpanzee mismatch (I510M) in the MAMLD1 amino acid sequence: chimpanzee wild-type (p.A505 \& p.M510), disease-causing in human, apparently wild-type in Neanderthal (p.A505 \& p.I510), and human wild-type (p.V505 \& p.I510). Since experimentally determined structures were not available, all three protein structures and the predicted ligand-protein binding sites had to be determined in silico using the I-TASSER server [Roy et al., 2010]. The C-score is a confidence score that quantifies the presumed quality of a protein model predicted by I-TASSER. C-scores are typically in the range of -5 to 2 , where a higher C-score indicates a greater degree of confidence in a given model. The models derived in the present analysis had C-scores in the range of -1.46 to 0.99 .

\section{Results}

\section{Identification of PCMs in the Neanderthal and/or chimpanzee genome}

A total of 44,348 missense mutations from 2,628 genes, logged in HGMD as being either causative of, or associated with, a human inherited disease state, were cross-compared to the corresponding nucleotide positions in the Neanderthal and chimpanzee genomes. HGMD-derived mutations at sites where the apparent wild-type nucleotide in Neanderthal and/or chimpanzee corresponded to the substituting nucleotide in humans ('potentially 
compensated mutations'; PCMs) were selected for further study. Although PCMs are most likely to be missense mutations, it nevertheless remains theoretically possible that PCMs also occur in other gene regions. Indeed, Kondrashov et al. [2002] argued that regulatory mutations may also be compensated for by the mediating effects of DNA- or RNA-binding proteins. For this reason, an additional 1,712 single base-pair substitutions from within the regulatory regions (5' and 3' untranslated/flanking regions) of 807 genes associated with human disease were retrieved from HGMD and were also included in this analysis.

Of the 122 PCMs identified (Table 2), 62 were missense mutations (Supp. Table S1) including five that were deemed to be disease-causing in humans (Table 3). Another 60 PCMs were disease-associated regulatory polymorphisms (Supp. Table S2). A total of 88 PCMs (72.1\%) were ancestral, i.e. the Neanderthal and chimpanzee nucleotides were identical ('A' state), whereas $33(27.0 \%)$ were derived, meaning that the Neanderthal nucleotide matched the human wild-type and that the PCM was confined to chimpanzee ('D' state) (Figure 1). Since being an A-state PCM implies that compensation, if any, must have occurred in both Neanderthal and chimpanzee, the 88 A-state PCMs (including two DMs) may serve to identify sites of adaptive difference between modern humans and Neanderthals. A D-state PCM, however, would only have required compensation in chimpanzee. For one of the $122 \mathrm{PCMs}$, namely a disease-associated functional polymorphism in the $F 7$ gene promoter (G/T at nucleotide -401; Supp. Table S2), the Neanderthal wild-type nucleotide matched the mutant state (-401T) as logged in HGMD, but differed from both the chimpanzee and human wild-type sequence [and hence constituted a third category ('N' state) in Table 2]. The -401T allele, which 
is rare in humans, is known to be associated with a reduced basal rate of transcription of the human F7 gene in vitro and with reduced plasma concentrations of total FVII antigen and activated FVII in vivo [van 't Hooft et al., 1999].

The number of A-state PCMs exceeded the number of D-state PCMs in every mutational category (Table 2) despite the fact that, among the missense and promoter mutations included in the Neanderthal nucleotide substitution dataset, the total numbers were 7,384 for state A and 47,391 for state D (data not shown). This discrepancy suggests that the vast majority of PCMs identified via HGMD (which it should be noted are actually polymorphisms rather than rare or private pathological mutations) have only acquired their phenotypic relevance fairly recently in the lineage leading to modern humans.

\section{Disease-causing PCMs in Neanderthal and/or chimpanzee?}

A total of five disease-causing human missense mutations were identified as PCMs in that they corresponded precisely to the alleles that were wild-type in Neanderthal and/or chimpanzee (Table 3). Two of these [DUOX2 (MIM\# 606759), MAMLD1 (MIM\# 300120)] were A-state in that the substituting residues in human matched the wild-type residues in both Neanderthal and chimpanzee. The DUOX2 mutation (H678R) is associated with autosomal recessive hypothyroidism whereas the MAMLD1 mutation (p.V505A) is associated with X-linked recessive hypospadias.

We next sought mutations in the DUOX2 and MAMLD1 genes that might have served to compensate for the deleterious effect of the respective PCM in chimpanzee and/or Neanderthal. 
Compensatory mutations appear to occur disproportionately in the vicinity of the sites of the original deleterious (i.e. compensated) mutations [Davis et al., 2009]. However, only in MAMLD1 did pair-wise alignment reveal a potentially compensating chimpanzee amino acid residue (p.M510) in the vicinity of the human disease-causing mutation (p.V505A). Residue 510 is a methionine not only in chimpanzee but also in all other primates investigated, with the sole exceptions of human and Neanderthal where isoleucine is present at this location (Figure 2). Interestingly, protein structure modeling predicted that the combination of p.V505 and p.I510 (i.e. the human wild-type) would introduce a novel nucleic acid-protein binding site (Figure 2) that would not have been present in either chimpanzee or Neanderthal (and which would have been abolished by the hypospadias-causing p.V505A mutation). These findings suggest that the nucleotide substitutions giving rise to a valine at p.505 and an isoleucine at p.510 may have exerted a cooperative effect which allowed both of them to become fixed during human evolution.

One of the three disease-causing D-state PCMs (Table 3), the SLC5A1 (MIM\# 182380) H615Q substitution, is thought to be responsible for recessive glucose/galactose malabsorption in human, and could represent an example of a clinically significant mutation that is present in both modern humans and chimpanzees. The second D-state PCM, a mutation in IL12RBI (MIM\# 601604), is also associated with a recessive condition in humans (susceptibility to mycobacterial infection). Intriguingly, the third D-state PCM, a mutation of the EXT1 (MIM\# 608177) gene, occurs in the only amino acid residue that differs between the wild-type chimpanzee and human EXT1 proteins. Thus, this mutation cannot be a classic compensated 
mutation (i.e. accompanied by a compensatory mutation in the immediate vicinity), but it could still conceivably be compensated for by non-allelic changes (between chimpanzee and human), for example in a protein binding partner. Although, in all three cases, the disease-causing mutation in human matches the wild-type residue in chimpanzees, the possible relevance to chimpanzee pathophysiology remains unclear.

\section{Pathophysiology of PCMs in modern humans and Neanderthals}

Upon Gene Ontology (GO) enrichment analysis, genes that contained PCMs (both missense and regulatory) in Neanderthal were found to be significantly enriched in functions related to the immune system and stimulus response (Table 4). This finding is consistent with previous reports of immune response genes having been subject to positive selection during primate evolution [Nielsen et al., 2005; Vamathevan et al., 2008; Enard et al., 2010]. It is clearly not possible, however, on the basis of this GO analysis, to extrapolate from human to Neanderthals.

\section{Human variants with different population frequencies at sites of PCMs}

Of the 86 ancestral polymorphic PCMs identified in our study (i.e. categories DP, FP and DFP in Table 2), 19 were characterized by at least one nominally significant allele frequency difference between extant African and non-African human populations (International HapMap Consortium, 2007; Table 5). This represents a more than two-fold excess over random expectation $(2 \times 0.05 \times 86=8.6)$. We used Wright's fixation index $F_{S T}$ to quantify the degree of genetic divergence between the different populations at these loci. Alleles that have been the 
target of localized positive selection tend to exhibit unusually high $\mathrm{F}_{\mathrm{ST}}$ values [Thornton and Jensen, 2007; Holsinger and Weir, 2009]. Therefore, we compared the $F_{\text {ST }}$ values of the ancestral polymorphic PCMs to the empirical $\mathrm{F}_{\mathrm{ST}}$ distribution derived from all HapMap SNPs [International HapMap Consortium, 2007] to assess the significance of individual $\mathrm{F}_{\mathrm{ST}}$ values. Previous analysis has shown that the average pair-wise $\mathrm{F}_{\mathrm{ST}}$ for Africans and Asians is around 0.19, compared to 0.15 for Africans and Europeans [International HapMap Consortium, 2007]. The 19 PCMs mentioned above exhibited at least one pair-wise $\mathrm{F}_{\mathrm{ST}}$ value between Africans and Asians or Europeans of 0.4 or higher, consistent with the differential action of recent positive selection in these populations.

The highest $\mathrm{F}_{\mathrm{ST}}$ values were observed for a disease-associated/functional polymorphism (K121Q; AAG>CAG) in the ENPP1 (MIM\# 173335) gene (Table 5; Supp. Table S2), that is associated with insulin resistance and obesity in modern humans. This variant, which exhibited particularly high pair-wise $\mathrm{F}_{\mathrm{ST}}$ values in our comparison of African and non-African populations (Table 5), occurs within a chromosomal region that has been subject to a selective sweep in early humans [Green et al., 2010]. The A allele of the polymorphism is human-specific and must have originated in the modern human lineage. Consistent with a strong environmental influence upon its maintenance, the increased risk of type-2 diabetes conferred by the alternative C (Q121) allele may be abolished by lifestyle intervention [Moore et al., 2009]. The reported success of a clinical intervention in this context provides ample retrospective justification for the identification and analysis of genetic susceptibility variants for human disease, even if only statistically associated. 


\section{Discussion}

Previous studies have shown that humans and Neanderthals shared some key evolutionary sequence changes (e.g. in the FOXP2 [MIM\# 605317; Krause et al., 2007], CMAH [MIM\# 603209; Chou et al., 2002] and AGAP1 [MIM\# 608651; Hünemeier et al., 2010] genes) which are absent from the chimpanzee genome. In addition, the two hominins have been shown to have had polymorphisms in the $A B O$ blood group [MIM\# 110300; Lalueza-Fox et al., 2008], MCPH1 [MIM\# 607117; Lari et al., 2010] and TAS2R38 taste receptor [MIM\# 607751; Lalueza-Fox et al., 2009] genes in common, testifying to their ancient origin. On the other hand, a Neanderthal-specific variant in the melanocortin 1 receptor (MC1R; MIM\# 155555) gene has also been reported [Lalueza-Fox et al., 2007]. Having sequenced the Neanderthal genome, Green et al. [2010] were able to identify a further 78 amino acid differences between the two hominins, with the derived allele having become fixed in modern humans whilst Neanderthals appear to have carried the ancestral (chimpanzee-like) allele.

The sequencing of the Neanderthal genome represents an outstanding scientific achievement and provides us with an invaluable resource for comparative genomic studies involving humans. However, when the resultant sequence data are employed in studies such as ours, there are various caveats that need to be considered. Firstly, the possibility of cross-contamination with modern human DNA is omnipresent [Wall and Kim, 2007]. Green et al. [2010] estimated that the extent of DNA contamination by modern human males is about $0.6 \%$ in the combined Neanderthal sequence data (with an upper $95 \%$ bound of $1.5 \%$ ). Secondly, artefactual $\mathrm{C}>\mathrm{T}$ and 
G>A substitutions, resulting from the time-dependent deamination of 5-methylcytosine post mortem, may be quite frequent although it is unclear precisely how frequent [Briggs et al., 2007; Briggs et al., 2010]. By contrast, other types of artefactual nucleotide substitution were found to occur at significantly lower frequencies [Green et al., 2010]. Thus, for $\mathrm{C}>\mathrm{T}$ and $\mathrm{G}>\mathrm{A}$ substitutions at $\mathrm{CpG}$ dinucleotides, it is very difficult to distinguish between bona fide germline mutations that occurred recurrently in both lineages and artefactual mutations that steadily accumulated in the DNA samples post mortem. One way in which post mortem CG>TG, CA mutations could have inadvertently altered our conclusions would have been if bona fide D-state sites had been mis-scored as A-state sites (i.e. false positives), thereby artificially inflating the number of A-state PCMs identified. To assess the potential for such a source of error, we compared the frequency of $\mathrm{CpG}$-located $\mathrm{C}>\mathrm{T}$ and $\mathrm{G}>\mathrm{A}$ substitutions among A-state PCMs (10/88; 0.11) with that in the HGMD missense and regulatory mutation dataset (8812/46060; 0.19). Owing to the nearly two-fold excess seen in HGMD, we may conclude that the Neanderthal genome sequence data reported by Green et al. [2010] are unlikely to have been compromised by any excess $\mathrm{CpG}$ mutations originating post mortem. The above notwithstanding, it should be appreciated that the attribution of an A-state has the potential to be somewhat misleading for mutations occurring within $\mathrm{CpG}$ sites because identical $\mathrm{C}>\mathrm{T}$ or $\mathrm{G}>\mathrm{A}$ transitions may have occurred quite independently in the Neanderthal and chimpanzee lineages as a consequence of high frequency methylation-mediated deamination of 5-methylcytosine in vivo.

We know comparatively little about health and disease in Neanderthals, who appear to have 17 John Wiley \& Sons, Inc. 
suffered from various systemic infections [Ember and Ember, 2004] and for whom both a natural kyphosis of the lumbar spine [Weber and Pusch, 2008] and osteochondromas/ exostoses [Trinkhaus, 2008] have been inferred from skeletal remains..Neanderthals and modern humans differed quite markedly in terms of craniofacial features; although Neanderthal brain size was similar at birth to that of modern humans, brain growth rates during early infancy may have been higher [Ponce de León and Zollikofer, 2001; Ponce de León et al., 2008]. With the above in mind, the A761V amino acid sequence polymorphism (associated with cranial volume) identified as a PCM in the MCPH1 (MIM\# 607117) gene is intriguing, as is the V537I polymorphism (associated with osteochondromas/exostoses) identified as a PCM in the EXT1 gene (Supp. Table S1). It may also be pertinent to note that, of the 60 regulatory PCMs in Neanderthal or chimpanzee (listed in Supp. Table S2), four are associated with body fat/obesity, five are associated with lipid metabolism, five are associated with insulin resistance/diabetes, three are associated with asthma, and two are associated with resistance to infection.

Green et al. [2010] identified a number of genetic regions that were involved in gene flow from Neanderthals to non-African modern humans. One of these regions harbours the abovementioned SLC5A1 H>Q mutation, responsible for the disease phenotype 'glucose/galactose malabsorption'. However, since there is no difference in allele frequency between Africans and non-Africans (a finding which could also be explicable in terms of balancing selection), this lesion would appear not to have originated via gene-flow from Neanderthals.

The idea that two individually deleterious mutations might be capable of restoring normal 18 John Wiley \& Sons, Inc. 
fitness when they occur in combination can be traced back to Kimura [1985] who suggested that 'compensatory neutral mutations' might play an important role in evolution. More recently, Kondrashov et al. [2002] compared pathological missense mutations in 32 human proteins to the amino acid substitutions that occurred during the course of evolution of these same proteins, and estimated that $\sim 10 \%$ of all amino acid sequence differences between a human protein and a non-human (mammalian) orthologue could represent what they termed 'compensated pathogenic deviations' (CPDs), essentially equivalent to the PCMs discussed here. Since CPDs would be pathogenic in humans, Kondrashov et al. [2002] surmised that the normal functioning of a CPD-containing protein in the non-human species must be due to other (compensatory) amino acid sequence deviations from the human sequence. In other words, as many as $10 \%$ of all the amino acid substitutions that become fixed in an evolving protein may be dependent upon compensatory substitutions to be benign. It is assumed that the compensatory mutations serve to neutralize the potential detrimental effect of the compensated mutation on the structure and stability of the protein [Ferrer-Costa et al., 2007].

With the sequencing of the genomes of various model organisms, numerous examples have emerged of compensated mutations i.e. human pathological missense mutations where the substituting amino acid has been found to be identical to the wild-type amino acid residue at the orthologous position in mouse [Gao and Zhang 2003], macaque [Gibbs et al., 2007] or chimpanzee [Mikkelsen et al., 2005; Azevedo et al., 2006]. This apparent paradox is potentially explicable in terms of the 'compensatory mutation hypothesis' which holds that the absence of strongly deleterious effects in other mammalian species is due to the buffering effect of epistatic 
interactions between the mutation which causes disease in human (the 'compensated mutation') and other mutational changes that compensate in some way for the functional alteration in the mammalian protein (the 'compensatory mutations'). In principle, these compensatory changes could be either allelic to the compensated mutation or non-allelic. It is assumed that the compensatory mutations, present in the non-human protein, serve to neutralize the potential detrimental effect of the compensated mutation on the structure of the protein [Ferrer-Costa $e t$ al., 2007]. In evolution, compensatory mutations are unlikely to occur singly; indeed, Poon et al. [2005] have suggested that an average of 11.8 compensatory mutations may interact epistatically with a given deleterious mutation so as to restore wild-type levels of fitness. CPDs tend to be less severe in terms of the physicochemical difference between the substituted and substituting amino acids than normally pathological mutations [Ferrer-Costa et al., 2007; Barešić et al., 2010]. Barešić et al. [2010] have also shown that amino acid residues surrounding the compensated residue in the folded protein are mutated more often than residues surrounding an uncompensated mutation, consistent with the view that compensation relies upon structurally local mutations.

Consistent with the idea that common disease susceptibility may be the result of long-term human adaptation to a steady ancient environment, a number of the alleles that increase the risk of common diseases are indeed ancient [Di Rienzo \& Hudson 2005; Corona et al., 2010]. In this framework, the newly acquired allele confers protection against the disease. The human risk alleles could correspond to either persistent (i.e. ancient) or recurring mutations that represent the recapitulation of ancestral states that may once have been protective, but which 
now result in adverse consequences for human health. If compensated mutations are more likely to be fixed by positive selection than by drift [Corona et al., 2010], then these variants could indeed represent adaptive differences.

Here we have performed triangulation of human, chimpanzee and Neanderthal genome sequence data and cross-compared the chromosomal coordinates of the recognized sequence differences with known human disease-related mutations. A total of 122 mutations were identified (62 of which were missense mutations including five deemed to be disease-causing in humans) that were potentially compensated in chimpanzee or Neanderthal. Of these 122 human mutations, termed PCMs, 88 were 'ancestral' in that the PCM matched the wild-type in both non-human species whereas 33 were 'derived' in that the Neanderthal wild-type matched the human wild-type (i.e. the PCM was confined to chimpanzee). The 88 ancestral PCMs could potentially be indicative of genomic regions that harbour adaptive differences between modern humans and Neanderthals. 'Ancestral' PCMs that are disease-causing in humans were identified in two human genes (DUOX2, MAMLD1). These pathological lesions could thus provide examples of compensated mutations in Neanderthal but, since all these mutations give rise to recessively inherited conditions in humans, it is also possible that they could have been associated with disease causation/susceptibility in Neanderthals. Intriguingly, we identified 19 PCMs in both Neanderthals and chimpanzees that are polymorphic in human and that exhibit nominally significant frequency differences between the African and at least one non-African population. These PCMs represent major candidates for recent population-specific selection, consistent with different alleles having exhibited differential functional importance in different 
environments.

\title{
References
}

Adzhubei IA, Schmidt S, Peshkin L, Ramensky VE, Gerasimova A, Bork P, Kondrashov AS, Sunyaev SR. 2010. A method and server for predicting damaging missense mutations. Nat Methods 7:248-249.

\begin{abstract}
Azevedo L, Suriano G, van Asch B, Harding RM, Amorim A. 2006. Epistatic interactions: how strong in disease and evolution? Trends Genet 22:581-585.
\end{abstract}
Bakewell MA, Shi P, Zhang J. 2007. More genes underwent positive selection in chimpanzee evolution than in human evolution. Proc Natl Acad Sci USA 104:7489-7494.

Banks WE, d'Errico F, Peterson AT, Kageyama M, Sima A, Sánchez-Goñi MF. 2008. Neanderthal extinction by competitive exclusion. PLoS One 3:e3972.
Barešić A, Hopcroft LE, Rogers HH, Hurst JM, Martin AC. 2009. Compensated pathogenic deviations: analysis of structural effects. J Mol Biol 396:19-30.


Benjamini Y, Hochberg Y. 1995. Controlling the false discovery rate: a practical and powerful approach to multiple testing. J Roy Stat Soc Series B (Methodological) 57:289-300.

Briggs AW, Stenzel U, Johnson PL, Green RE, Kelso J, Prüfer K, Meyer M, Krause J, Ronan MT, Lachmann M, Pääbo S. 2007. Patterns of damage in genomic DNA sequences from a Neandertal. Proc Natl Acad Sci USA 104:14616-14621.

Briggs AW, Stenzel U, Meyer M, Krause J, Kircher M, Pääbo S. (2010) Removal of deaminated cytosines and detection of in vivo methylation in ancient DNA. Nucleic Acids Res 38:e87.

Chou HH, Hayakawa T, Diaz S, Krings M, Indriati E, Leakey M, Paabo S, Satta Y, Takahata N, Varki A. 2002. Inactivation of CMP- $N$-acetylneuraminic acid hydroxylase occurred prior to brain expansion during human evolution. Proc Natl Acad Sci USA 99:11736-11741.

Clark AG, Glanowski S, Nielsen R, Thomas PD, Kejariwal A, Todd MA, Tanenbaum DM, Civello D, Lu F, Murphy B, Ferriera S, Wang G, Zheng X, White TJ, Sninsky JJ, Adams MD, Cargill M. 2003. Inferring nonneutral evolution from human-chimp-mouse orthologous gene trios. Science 302:1960-1963.

Corona E, Dudley JT, Butte AJ. 2010. Extreme evolutionary disparities seen in positive selection across seven complex diseases. PLoS ONE 5:e12236. 
Davis BH, Poon AF, Whitlock MC. 2009. Compensatory mutations are repeatable and clustered within proteins. Proc Biol Sci 276:1823-1827

Di Rienzo A, Hudson RR. 2005. An evolutionary framework for common diseases: the ancestral-susceptibility model. Trends Genet 21:596-601.

Ember CR, Ember M (Eds). 2004. Encyclopedia of Medical Anthropology: Health and Illness in the World's Cultures. Springer, New York.

Enard D, Depaulis F, Roest Crollius H. 2010. Human and non-human primate genomes share hotspots of positive selection. PLoS Genet 6:e1000840.

Ferrer-Costa C, Orozco M, de la Cruz X. 2007. Characterization of compensated mutations in terms of structural and physico-chemical properties. J Mol Biol 365:249-256.

Gao L, Zhang J. 2003. Why are some human disease-associated mutations fixed in mice? Trends Genet 19:678-681.

Gibbs RA, Rogers J, Katze MG, Bumgarner R, Weinstock GM, Mardis ER, Remington KA, Strausberg RL, Venter JC, Wilson RK, Batzer MA, Bustamante CD, Eichler EE, Hahn MW, 
Hardison RC, Makova KD, Miller W, Milosavljevic A, Palermo RE, Siepel A, Sikela JM, Attaway T, Bell S, Bernard KE, Buhay CJ, Chandrabose MN, Dao M, Davis C, Delehaunty KD, Ding Y, Dinh HH, Dugan-Rocha S, Fulton LA, Gabisi RA, Garner TT, Godfrey J, Hawes AC, Hernandez J, Hines S, Holder M, Hume J, Jhangiani SN, Joshi V, Khan ZM, Kirkness EF, Cree A, Fowler RG, Lee S, Lewis LR, Li Z, Liu YS, Moore SM, Muzny D, Nazareth LV, Ngo DN, Okwuonu GO, Pai G, Parker D, Paul HA, Pfannkoch C, Pohl CS, Rogers YH, Ruiz SJ, Sabo A, Santibanez J, Schneider BW, Smith SM, Sodergren E, Svatek AF, Utterback TR, Vattathil S, Warren W, White CS, Chinwalla AT, Feng Y, Halpern AL, Hillier LW, Huang X, Minx P, Nelson JO, Pepin KH, Qin X, Sutton GG, Venter E, Walenz BP, Wallis JW, Worley KC, Yang SP, Jones SM, Marra MA, Rocchi M, Schein JE, Baertsch R, Clarke L, Csürös M, Glasscock J, Harris RA, Havlak P, Jackson AR, Jiang H, Liu Y, Messina DN, Shen Y, Song HX, Wylie T, Zhang L, Birney E, Han K, Konkel MK, Lee J, Smit AF, Ullmer B, Wang H, Xing J, Burhans R, Cheng Z, Karro JE, Ma J, Raney B, She X, Cox MJ, Demuth JP, Dumas LJ, Han SG, Hopkins J, Karimpour-Fard A, Kim YH, Pollack JR, Vinar T, Addo-Quaye C, Degenhardt J, Denby A, Hubisz MJ, Indap A, Kosiol C, Lahn BT, Lawson HA, Marklein A, Nielsen R, Vallender EJ, Clark AG, Ferguson B, Hernandez RD, Hirani K, Kehrer-Sawatzki H, Kolb J, Patil S, Pu LL, Ren Y, Smith DG, Wheeler DA, Schenck I, Ball EV, Chen R, Cooper DN, Giardine B, Hsu F, Kent WJ, Lesk A, Nelson DL, O'brien WE, Prüfer K, Stenson PD, Wallace JC, Ke H, Liu XM, Wang P, Xiang AP, Yang F, Barber GP, Haussler D, Karolchik D, Kern AD, Kuhn RM, Smith KE, Zwieg AS. 2007. Evolutionary and biomedical insights from the rhesus macaque genome. Science 316: 222-234. 
Green RE, Krause J, Briggs AW, Maricic T, Stenzel U, Kircher M, Patterson N, Li H, Zhai W, Fritz MH, Hansen NF, Durand EY, Malaspinas AS, Jensen JD, Marques-Bonet T, Alkan C, Prüfer K, Meyer M, Burbano HA, Good JM, Schultz R, Aximu-Petri A, Butthof A, Höber B, Höffner B, Siegemund M, Weihmann A, Nusbaum C, Lander ES, Russ C, Novod N, Affourtit J, Egholm M, Verna C, Rudan P, Brajkovic D, Kucan Z, Gusic I, Doronichev VB, Golovanova LV, Lalueza-Fox C, de la Rasilla M, Fortea J, Rosas A, Schmitz RW, Johnson PL, Eichler EE, Falush D, Birney E, Mullikin JC, Slatkin M, Nielsen R, Kelso J, Lachmann M, Reich D, Pääbo S. 2010. A draft sequence of the Neanderthal genome. Science 328:710-722.

Holsinger KE, Weir BS. 2009. Genetics in geographically structured populations: defining,

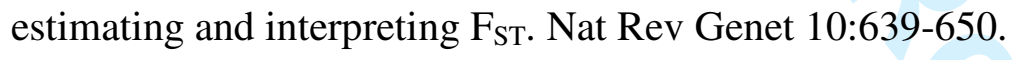

Hünemeier T, Ruiz-Linares A, Silveira A, Paixão-Côrtes VR, Salzano FM, Bortolini MC. 2010. Population data support the adaptive nature of HACNS1 sapiens/neandertal-chimpanzee differences in a limb expression domain. Am J Phys Anthropol In press.

International HapMap Consortium, Frazer KA, Ballinger DG, Cox DR, Hinds DA, Stuve LL, Gibbs RA, Belmont JW, Boudreau A, Hardenbol P, Leal SM, Pasternak S, Wheeler DA, Willis TD, Yu F, Yang H, Zeng C, Gao Y, Hu H, Hu W, Li C, Lin W, Liu S, Pan H, Tang X, Wang J, Wang W, Yu J, Zhang B, Zhang Q, Zhao H, Zhao H, Zhou J, Gabriel SB, Barry R, Blumenstiel 
B, Camargo A, Defelice M, Faggart M, Goyette M, Gupta S, Moore J, Nguyen H, Onofrio RC,

Parkin M, Roy J, Stahl E, Winchester E, Ziaugra L, Altshuler D, Shen Y, Yao Z, Huang W, Chu X, He Y, Jin L, Liu Y, Shen Y, Sun W, Wang H, Wang Y, Wang Y, Xiong X, Xu L, Waye MM, Tsui SK, Xue H, Wong JT, Galver LM, Fan JB, Gunderson K, Murray SS, Oliphant AR, Chee MS, Montpetit A, Chagnon F, Ferretti V, Leboeuf M, Olivier JF, Phillips MS, Roumy S, Sallée C, Verner A, Hudson TJ, Kwok PY, Cai D, Koboldt DC, Miller RD, Pawlikowska L, Taillon-Miller P, Xiao M, Tsui LC, Mak W, Song YQ, Tam PK, Nakamura Y, Kawaguchi T, Kitamoto T, Morizono T, Nagashima A, Ohnishi Y, Sekine A, Tanaka T, Tsunoda T, Deloukas P, Bird CP, Delgado M, Dermitzakis ET, Gwilliam R, Hunt S, Morrison J, Powell D, Stranger BE, Whittaker P, Bentley DR, Daly MJ, de Bakker PI, Barrett J, Chretien YR, Maller J, McCarroll S, Patterson N, Pe'er I, Price A, Purcell S, Richter DJ, Sabeti P, Saxena R, Schaffner SF, Sham PC, Varilly P, Altshuler D, Stein LD, Krishnan L, Smith AV, Tello-Ruiz MK, Thorisson GA, Chakravarti A, Chen PE, Cutler DJ, Kashuk CS, Lin S, Abecasis GR, Guan W, Li Y, Munro HM, Qin ZS, Thomas DJ, McVean G, Auton A, Bottolo L, Cardin N, Eyheramendy S, Freeman C, Marchini J, Myers S, Spencer C, Stephens M, Donnelly P, Cardon LR, Clarke G, Evans DM, Morris AP, Weir BS, Tsunoda T, Mullikin JC, Sherry ST, Feolo M, Skol A, Zhang H, Zeng C, Zhao H, Matsuda I, Fukushima Y, Macer DR, Suda E, Rotimi CN, Adebamowo CA, Ajayi I, Aniagwu T, Marshall PA, Nkwodimmah C, Royal CD, Leppert MF, Dixon M, Peiffer A, Qiu R, Kent A, Kato K, Niikawa N, Adewole IF, Knoppers BM, Foster MW, Clayton EW, Watkin J, Gibbs RA, Belmont JW, Muzny D, Nazareth L, Sodergren E, Weinstock GM, Wheeler DA, Yakub I, Gabriel SB, Onofrio RC, Richter DJ, Ziaugra L, Birren 
BW, Daly MJ, Altshuler D, Wilson RK, Fulton LL, Rogers J, Burton J, Carter NP, Clee CM, Griffiths M, Jones MC, McLay K, Plumb RW, Ross MT, Sims SK, Willey DL, Chen Z, Han H, Kang L, Godbout M, Wallenburg JC, L'Archevêque P, Bellemare G, Saeki K, Wang H, An D, Fu H, Li Q, Wang Z, Wang R, Holden AL, Brooks LD, McEwen JE, Guyer MS, Wang VO, Peterson JL, Shi M, Spiegel J, Sung LM, Zacharia LF, Collins FS, Kennedy K, Jamieson R, Stewart J. 2007. A second generation human haplotype map of over 3.1 million SNPs. Nature 449:851-861.

Kehrer-Sawatzki H, Cooper DN. 2007. Understanding the recent evolution of the human genome: insights from human-chimpanzee genome comparisons. Hum Mutat 28:99-130.

Kimura M. 1985. The role of compensatory neutral mutations in molecular evolution. J Genet 64: 7-19.

Kondrashov AS, Sunyaev S, Kondrashov FA. 2002. Dobzhansky-Muller incompatibilities in protein evolution. Proc Natl Acad Sci USA 99:14878-14883.

\footnotetext{
Krause J, Lalueza-Fox C, Orlando L, Enard W, Green RE, Burbano HA, Hublin JJ, Hänni C, Fortea J, de la Rasilla M, Bertranpetit J, Rosas A, Pääbo S. 2007. The derived FOXP2 variant of modern humans was shared with Neanderthals. Curr Biol 17:1908-1912.
} 
Lalueza-Fox C, Römpler H, Caramelli D, Stäubert C, Catalano G, Hughes D, Rohland N, Pilli

E, Longo L, Condemi S, de la Rasilla M, Fortea J, Rosas A, Stoneking M, Schöneberg T, Bertranpetit J, Hofreiter M. 2007. A melanocortin 1 receptor allele suggests varying pigmentation among Neanderthals. Science 318:1453-1455.

Lalueza-Fox C, Gigli E, de la Rasilla M, Fortea J, Rosas A, Bertranpetit J, Krause J. 2008. Genetic characterization of the ABO blood group in Neanderthals. BMC Evol Biol 8:342.

Lalueza-Fox C, Gigli E, de la Rasilla M, Fortea J, Rosas A. 2009. Bitter taste perception in Neanderthals through the analysis of the TAS2R38 gene. Biol Lett 5:809-811.

Lari M, Rizzi E, Milani L, Corti G, Balsamo C, Vai S, Catalano G, Pilli E, Longo L, Condemi S, Giunti P, Hänni C, De Bellis G, Orlando L, Barbujani G, Caramelli D. 2010. The microcephalin ancestral allele in a Neanderthal individual. PLoS One 5:e10648.

Marques-Bonet T, Ryder OA, Eichler EE. 2009. Sequencing primate genomes: what have we learned? Annu Rev Genomics Hum Genet 10:355-386.

Mellars P. 2004. Neanderthals and the modern human colonization of Europe. Nature 432:461-465. 
Mikkelsen TS, Hillier LW, Eichler EE, Zody MC, JaVe DB, Yang S-P, Enard W, Hellmann I, Lindblad-Toh K, Altheide TK, Archidiacono N, Bork P, Butler J, Chang JL, Cheng Z, Chinwalla AT, deJong P, Delehaunty KD, Fronick CC, Fulton LL, Gilad Y, Glusman G, Gnerre S, Graves TA, Hayakawa T, Hayden KE, Huang X, Ji H, Kent WJ, King M-C, Kulbokas EJ, Lee MK, Liu G, Lopez-Otin C, Makova KD, Man O, Mardis ER, Mauceli E, Miner TL, Nash WE, Nelson JO, Pääbo S, Patterson NJ, Poh CS, Pollard KS, Prüfer K, Puente XS, Reich D, Rocchi M, Rosenbloom K, Ruvolo M, Richter DJ, SchaVner SF, Smit AFA, Smith SM, Suyama M, Taylor J, Torrents D, Tuzun E, Varki A, Velasco G, Ventura M, Wallis JW, Wend MC, Wilson RK, Lander ES, Waterston RJ. 2005. Initial sequence of the chimpanzee genome and comparison with the human genome. Nature 437:69-87.

Moore AF, Jablonski KA, Mason CC, McAteer JB, Arakaki RF, Goldstein BJ, Kahn SE,

Kitabchi AE, Hanson RL, Knowler WC, Florez JC; Diabetes Prevention Program Research Group. 2009. The association of ENPP1 K121Q with diabetes incidence is abolished by lifestyle modification in the diabetes prevention program. J Clin Endocrinol Metab 94:449-455.

Nielsen R, Bustamante C, Clark AG, Glanowski S, Sackton TB, Hubisz MJ, Fledel-Alon A, Tanenbaum DM, Civello D, White TJ, J Sninsky J, Adams MD, Cargill M. 2005. A scan for positively selected genes in the genomes of humans and chimpanzees. PLoS Biol 3:e170.

Nielsen R, Hellmann I, Hubisz M, Bustamante C, Clark AG. 2007. Recent and ongoing 30 John Wiley \& Sons, Inc. 
selection in the human genome. Nat Rev Genet 8:857-868.

Noonan JP, Coop G, Kudaravalli S, Smith D, Krause J, Alessi J, Chen F, Platt D, Pääbo S, Pritchard JK, Rubin EM. 2006. Sequencing and analysis of Neanderthal genomic DNA. Science $314: 1113-1118$.

Noonan JP. 2010. Neanderthal genomics and the evolution of modern humans. Genome Res 20:547-553.

Ponce de León MS, Zollikofer CP. 2001. Neanderthal cranial ontogeny and its implications for late hominid diversity. Nature 412:534-538

Ponce de León MS, Golovanova L, Doronichev V, Romanova G, Akazawa T, Kondo O, Ishida H, Zollikofer CP. 2008. Neanderthal brain size at birth provides insights into the evolution of human life history. Proc Natl Acad Sci USA 105:13764-13768.

Poon A, Davis BH, Chao L. 2005. The coupon collector and the suppressor mutation: estimating the number of compensatory mutations by maximum likelihood. Genetics 170:1323-1332.

Roy A, Kucukural A, Zhang Y. 2010. I-TASSER: a unified platform for automated protein 
structure and function prediction. Nature Protocols 5:725-738.

Stenson PD, Mort M, Ball EV, Howells K, Phillips AD, Thomas NS, Cooper DN. 2009. The Human Gene Mutation Database: 2008 update. Genome Med 1:13.

Suriano G, Azevedo L, Novais M, Boscolo B, Seruca R, Amorim A, Ghibaudi EM. 2007. In vitro demonstration of intra-locus compensation using the ornithine transcarbamylase protein as model. Hum Mol Genet 16:2209-2214.

Thornton KR, Jensen JD. 2007. Controlling the false-positive rate in multilocus genome scans for selection. Genetics 175:737-750.

Trinkhaus E, Maley B, Buzhilova AP. 2008. Paleopathology of the Kiik-Koba 1 Neandertal. Am J Phys Anthropol 137:106-112.

Tzedakis PC, Hughen KA, Cacho I, Harvati K. 2007. Placing late Neanderthals in a climatic context. Nature 449:206-208.

\footnotetext{
Vamathevan JJ, Hasan S, Emes RD, Amrine-Madsen H, Rajagopalan D, Topp SD, Kumar V, Word M, Simmons MD, Foord SM, Sanseau P, Yang Z, Holbrook JD. 2008. The role of positive selection in determining the molecular cause of species differences in disease. BMC Evol Biol 
$8: 273$.

van 't Hooft FM, Silveira A, Tornvall P, Iliadou A, Ehrenborg E, Eriksson P, Hamsten A. 1999. Two common functional polymorphisms in the promoter region of the coagulation factor VII gene determining plasma factor VII activity and mass concentration. Blood 93:3432-3441.

Wall JD, Kim SK. 2007. Inconsistencies in Neanderthal genomic DNA sequences. PLoS Genet 3:e175.

Weber J, Pusch CM. 2008. The lumbar spine in Neanderthals shows natural kyphosis. Eur Spine J 17 Suppl 2:S327-330.

Weir BS, Hill WG. 2002. Estimating F-statistics. Annu Rev Genet 36:721-750.

\section{Figure legends}

Figure 1: Potential compensated mutations (PCMs) identified by genomic triangulation.

(A) 88 PCMs were ancestral, i.e. the Neanderthal and chimpanzee nucleotides were identical (ancestral state). (B) 33 PCMs were derived, denoting that the Neanderthal nucleotide matched the human wild-type nucleotide and that the PCM was confined to chimpanzee (derived state). An ancestral PCM should be compensated for in both Neanderthal and chimpanzee. By 
contrast, a derived PCM would only have required compensation in chimpanzee.

Figure 2: A potential example of a compensating amino acid residue (p.M510) in the chimpanzee MAMLD1 protein in the vicinity of the PCM at amino acid residue p.A505. (A) Multiple alignment of the orthologous regions of the MAMLD1 protein for a variety of primate species. In human wild-type MAMLD1, the combination of p.V505 and p.I510 is predicted by protein modelling to introduce a novel human-specific ligand-protein binding site (which would be abolished by the hypospadias-causing p.V505A mutation). (B) Predicted protein-ligand complex. MAMLD1 residues that interact with the ligand are coloured yellow. The p.V505 and p.I510 residues are shown in red with green highlighting. 
Table 1. Missense and regulatory mutations from HGMD used in this study, categorised by mutation type and putative role in disease aetiology

\begin{tabular}{|l|l|l|l|l|l|}
\hline \multirow{2}{*}{$\begin{array}{l}\text { Mutation/ } \\
\text { polymorphism type }\end{array}$} & \multicolumn{5}{|l|}{ Type and putative role in disease aetiology } \\
\cline { 2 - 6 } & DM & DP & DFP & FP & Total \\
\hline Missense & 41,960 & 942 & 295 & 1,151 & 44,348 \\
\hline Regulatory & 635 & 340 & 391 & 346 & 1,712 \\
\hline Total & 42,595 & 1,282 & 686 & 1,497 & 46,060 \\
\hline
\end{tabular}

DM: disease-causing mutation; DP: disease-associated polymorphism lacking functional evidence; DFP: disease-associated polymorphism with functional evidence; FP:

polymorphism with functional evidence, but lacking a reported disease association as yet. 
Table 2. HGMD-derived mutations identified as potentially compensated mutations (PCMs) in the Neanderthal and/or chimpanzee genome

\begin{tabular}{|l|l|l|l|l|l|l|l|}
\hline \multirow{2}{*}{$\begin{array}{l}\text { Mutation/ } \\
\text { polymorphism } \\
\text { type }\end{array}$} & \multicolumn{6}{|l|}{ Mutation type and basis of disease aetiology } & Neanderthal \\
\cline { 2 - 8 } & PCM state & DM & DP & FP & DFP & Total & \\
\hline \multirow{2}{*}{ Missense } & A & 2 & 25 & 6 & 14 & 47 & 3,703 \\
& D & 3 & 9 & 2 & 1 & 15 & 21,655 \\
\cline { 2 - 8 } & Total & 5 & 34 & 8 & 15 & 62 & 25,358 \\
\hline Regulatory & A & 0 & 20 & 10 & 11 & 41 & 3,681 \\
& D & 0 & 9 & 6 & 3 & 18 & 25,736 \\
\cline { 2 - 8 } & Total & 0 & 29 & 16 & 15 & 60 & 29,471 \\
\hline
\end{tabular}

A: ancestral (i.e. Neanderthal nucleotide identical to both the chimpanzee wild-type nucleotide and the human disease-causing/disease-associated mutation, but not the human wild-type nucleotide); D: derived (i.e. Neanderthal nucleotide identical to the human wild-type but not the chimpanzee wild-type nucleotide, which is identical to the human disease-causing/disease-associated mutation); $\mathrm{N}$ : Neanderthal wild-type identical to the human disease-causing/disease-associated mutation, but not to the chimpanzee or the human wild-type nucleotide. For further details, see legend to Table 1. 
Table 3. Human disease-causing mutations (DMs) identified as PCMs in chimpanzee and/or Neanderthal

\begin{tabular}{|c|c|c|c|c|c|c|}
\hline \multirow{2}{*}{$\begin{array}{l}\text { Gene } \\
\text { SLC5A1 }\end{array}$} & \multirow{2}{*}{$\begin{array}{l}\text { Mutation } \\
\mathrm{C}=>\mathrm{G}: \mathrm{CG}\end{array}$} & $\begin{array}{l}\text { HGVS nomenclature } \\
\text { (cDNA)HGVS nomencla } \\
\text { (protein) }\end{array}$ & $\begin{array}{l}\text { PCM } \\
\text { state }\end{array}$ & \multicolumn{2}{|l|}{ Disease phenotype } & \multirow{2}{*}{$\begin{array}{l}\text { Glucose/galactose } \\
\text { malabsorption }\end{array}$} \\
\hline & & NM_000343.1:c.1845C>G & $\mathrm{NP}$ & P_000334.1:p.H615Q & $\mathrm{D}$ & \\
\hline EXT1 & $\mathrm{G}=>\mathrm{A}: \mathrm{GA}$ & NM_000127.2:c.1609G >A & NP & P_000118.2:p.V537I & $\mathrm{D}$ & Multiple osteochondromas \\
\hline ILI2RBI & $A=>G: A G$ & NM_005535.1:c.641A>G & $\mathrm{NP}$ & P_005526.1:p.Q214R & $\mathrm{D}$ & $\begin{array}{l}\text { Mycobacterial infection, } \\
\text { susceptibility to }\end{array}$ \\
\hline$D U O X 2$ & $\mathrm{~A}=>\mathrm{G}: \mathrm{GG}$ & NM_014080.4:c.2033A>G & \begin{tabular}{l|l}
$\mathrm{NP}$ \\
\end{tabular} & P_054799.4:p.H678R & A & Hypothyroidism \\
\hline MAMLDI & $\mathrm{T}=>\mathrm{C}: \mathrm{CC}$ & NM_005491.2:c.1514T>C & & P_005482.2:p.V505A & A & Hypospadias \\
\hline
\end{tabular}

Mutations are given in the format human wild-type $=>$ human mutation: Neanderthal nucleotide, chimpanzee nucleotide. HGVS (cDNA) and HGVS (protein) represent mutation descriptions according to HGVS guidelines (www.hgvs.org/mutnomen) at the cDNA and protein levels, respectively. HGVS (cDNA) nomenclature provides cDNA numbering with +1 corresponding to the A of the ATG translational initiation codon in the corresponding reference sequence. HGVS (protein) nomenclature provides numbering relative to the reference protein sequence with the translational initiation codon $=1$. NM $\&$ NP denote NCBI RefSeq \& RefProt accession numbers respectively [http://www.ncbi.nlm.nih.gov/RefSeq/key.html]. For further details, see legends to Tables 1 and 2. 
Table 4. GO term enrichment for genes with potential compensatory mutations (in relation to Neanderthal) occurring specifically in modern humans

\begin{tabular}{|l|l|l|l|}
\hline GO ID & GO term & GO class & P \\
\hline GO:0002520 & immune system development & BP & 0.0034 \\
\hline GO:0048583 & regulation of response to stimulus & BP & 0.0040 \\
\hline GO:0002376 & immune system process & BP & 0.0040 \\
\hline GO:0002682 & regulation of immune system process & BP & 0.0220 \\
\hline GO:0005624 & membrane fraction & CC & 0.0220 \\
\hline GO:0050896 & response to stimulus & BP & 0.0220 \\
\hline GO:0000267 & cell fraction & CC & 0.0314 \\
\hline GO:0030225 & macrophage differentiation & BP & 0.0342 \\
\hline GO:0048534 & hemopoietic or lymphoid organ development & BP & 0.0342 \\
\hline GO:0002521 & leukocyte differentiation & BP & 0.0367 \\
\hline GO:0006955 & immune response & BP & 0.0367 \\
\hline GO:0010743 & regulation of foam cell differentiation & BP & 0.0416 \\
\hline GO:0030097 & hemopoiesis & BP & 0.0469 \\
\hline
\end{tabular}

BP: Biological process. CC: Cellular component. P: p-value from a hypergeometric distribution, adjusted for test multiplicity by consideration of the false discovery rate. 
Table 5. Ancestral polymorphic PCMs with significantly different genotype frequencies in different HapMap populations (http://hapmap.ncbi.nlm.nih.gov/)

\begin{tabular}{|c|c|c|c|c|c|c|c|c|c|c|c|c|}
\hline \multirow[t]{2}{*}{ Gene } & \multirow[t]{2}{*}{ rs number } & \multirow{2}{*}{$\begin{array}{c}\text { HGMD } \\
\text { Accession Number }\end{array}$} & \multicolumn{2}{|c|}{ Nucleotide } & \multicolumn{2}{|c|}{ Asian } & \multicolumn{2}{|c|}{ European } & \multicolumn{2}{|c|}{ African } & \multicolumn{2}{|c|}{ Pair-wise $F_{S T}$ (p value) } \\
\hline & & & WT & PCM & $f_{W T}$ & $\mathrm{n}$ & $f_{W T}$ & $\mathrm{n}$ & $\mathrm{f}_{\mathrm{WT}}$ & $\mathrm{n}$ & Asian-African & European-African \\
\hline ENPP1 & rs1044498 & CM993455 & A & $\mathrm{C}$ & 0.92 & 340 & 0.88 & 402 & 0.15 & 692 & $0.729(0.0046)$ & $0.690(0.0033)$ \\
\hline WRAP53 & rs2287499 & CM077855 & $\mathrm{C}$ & G & 0.72 & 176 & 0.84 & 120 & 0.08 & 120 & $0.575(0.0192)$ & $0.733(0.0020)$ \\
\hline$T P 53 B P 1$ & rs560191 & CM067475 & $\mathrm{C}$ & G & 0.52 & 178 & 0.69 & 120 & 0.00 & 120 & $0.472(0.0414)$ & $0.687(0.0034)$ \\
\hline$G H R H R^{*}$ & rs2302019 & CR066667 & $\mathrm{C}$ & $\mathrm{T}$ & 0.69 & 340 & 0.55 & 402 & 0.06 & 692 & $0.646(0.0105)$ & $0.486(0.0239)$ \\
\hline$L P L^{*}$ & rs1800590 & CR971950 & $\mathrm{T}$ & G & 1.00 & 176 & 0.98 & 120 & 0.48 & 114 & $0.576(0.0190)$ & $0.483(0.0245)$ \\
\hline TP53BP1 & rs2602141 & CM067476 & $\mathrm{A}$ & $\mathrm{C}$ & 0.59 & 340 & 0.67 & 400 & 0.09 & 692 & $0.480(0.0391)$ & $0.558(0.0129)$ \\
\hline THPO* & rs6141 & CR014438 & $\mathrm{G}$ & A & 0.53 & 340 & 0.42 & 402 & 0.01 & 586 & $0.580(0.0184)$ & $0.443(0.0337)$ \\
\hline$L T F$ & rs1126478 & CM096382 & A & G & 0.37 & 340 & 0.68 & 402 & 0.06 & 692 & $0.279(0.1397)$ & $0.619(0.0072)$ \\
\hline$U G T 1 A 1^{*}$ & rs4124874 & CR025220 & $\mathrm{T}$ & G & 0.68 & 340 & 0.56 & 402 & 0.12 & 690 & $0.517(0.0300)$ & $0.371(0.0566)$ \\
\hline$A B C B 1$ & rs2032582 & CM033585 & $\mathrm{T}$ & G & 0.57 & 340 & 0.45 & 402 & 0.05 & 464 & $0.507(0.0323)$ & $0.362(0.0603)$ \\
\hline$S L C 6 A 4 *$ & rs1042173 & CR084012 & $\mathrm{T}$ & G & 0.17 & 340 & 0.53 & 402 & 0.84 & 692 & $0.622(0.0130)$ & $0.217(0.1599)$ \\
\hline$V N N 1$ & rs4897612 & CR075274 & $\mathrm{T}$ & G & 0.63 & 340 & 0.68 & 400 & 0.17 & 692 & $0.382(0.0753)$ & $0.430(0.0370)$ \\
\hline$A R G 1 *$ & rs2781666 & CR073540 & G & $\mathrm{T}$ & 0.68 & 340 & 0.74 & 290 & 0.22 & 292 & $0.349(0.0922)$ & $0.427(0.0380)$ \\
\hline SFTPD & rs2243639 & CM067461 & $\mathrm{A}$ & G & 0.26 & 340 & 0.43 & 402 & 0.02 & 584 & $0.261(0.1557)$ & $0.431(0.0368)$ \\
\hline$E N P P 1 *$ & rs7754561 & CR052970 & $\mathrm{A}$ & G & 0.41 & 340 & 0.72 & 402 & 0.15 & 692 & $0.173(0.2568)$ & $0.507(0.0201)$ \\
\hline TLRI & rs4833095 & CM094340 & A & G & 0.32 & 336 & 0.70 & 402 & 0.12 & 690 & $0.110(0.3634)$ & $0.532(0.0162)$ \\
\hline C17orf53 & rs227584 & CM093418 & A & $\mathrm{C}$ & 0.26 & 340 & 0.70 & 400 & 0.12 & 690 & $0.068(0.4612)$ & $0.535(0.0158)$ \\
\hline$B C R$ & rs140504 & CM057927 & A & G & 0.49 & 340 & 0.12 & 402 & 0.03 & 692 & $0.494(0.0355)$ & $0.055(0.4664)$ \\
\hline$A G T$ & rs699 & CM920010 & $\mathrm{T}$ & $\mathrm{C}$ & 0.19 & 340 & 0.58 & 402 & 0.11 & 692 & $0.020(0.6231)$ & $0.415(0.0416)$ \\
\hline
\end{tabular}

WT: wild-type nucleotide in (non-African) human populations; PCM: potentially compensated mutation in the Neanderthal and chimpanzee genome; $f_{\mathrm{WT}}$ : frequency of the human wild-type allele in the respective population; $\mathrm{n}$ : sample size (number of chromosomes) in HapMap; $\mathrm{F}_{\mathrm{ST}}$ : small sample estimate of Wright's fixation index; $p$ value: as obtained by reference to the overall distribution of SNP-based pairwise $\mathrm{F}_{\mathrm{ST}}$ values in HapMap. Disease-associated/functional polymorphisms in gene regulatory regions are denoted by $*$. 
A

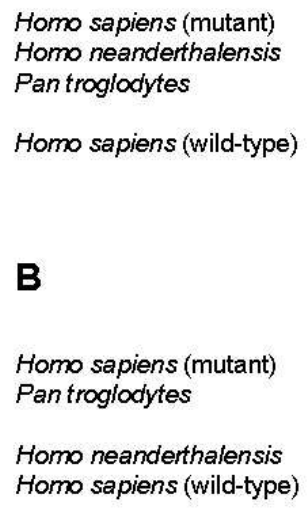

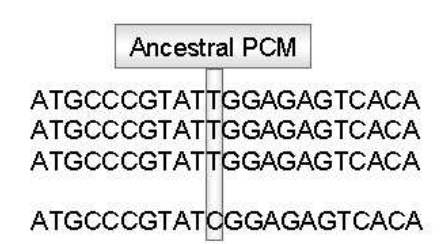

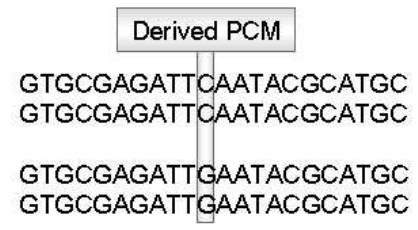


A

Human

Neanderthal

Chimpanzee

Gorilla

orangutan

Macaque

Marmoset

Bushbaby
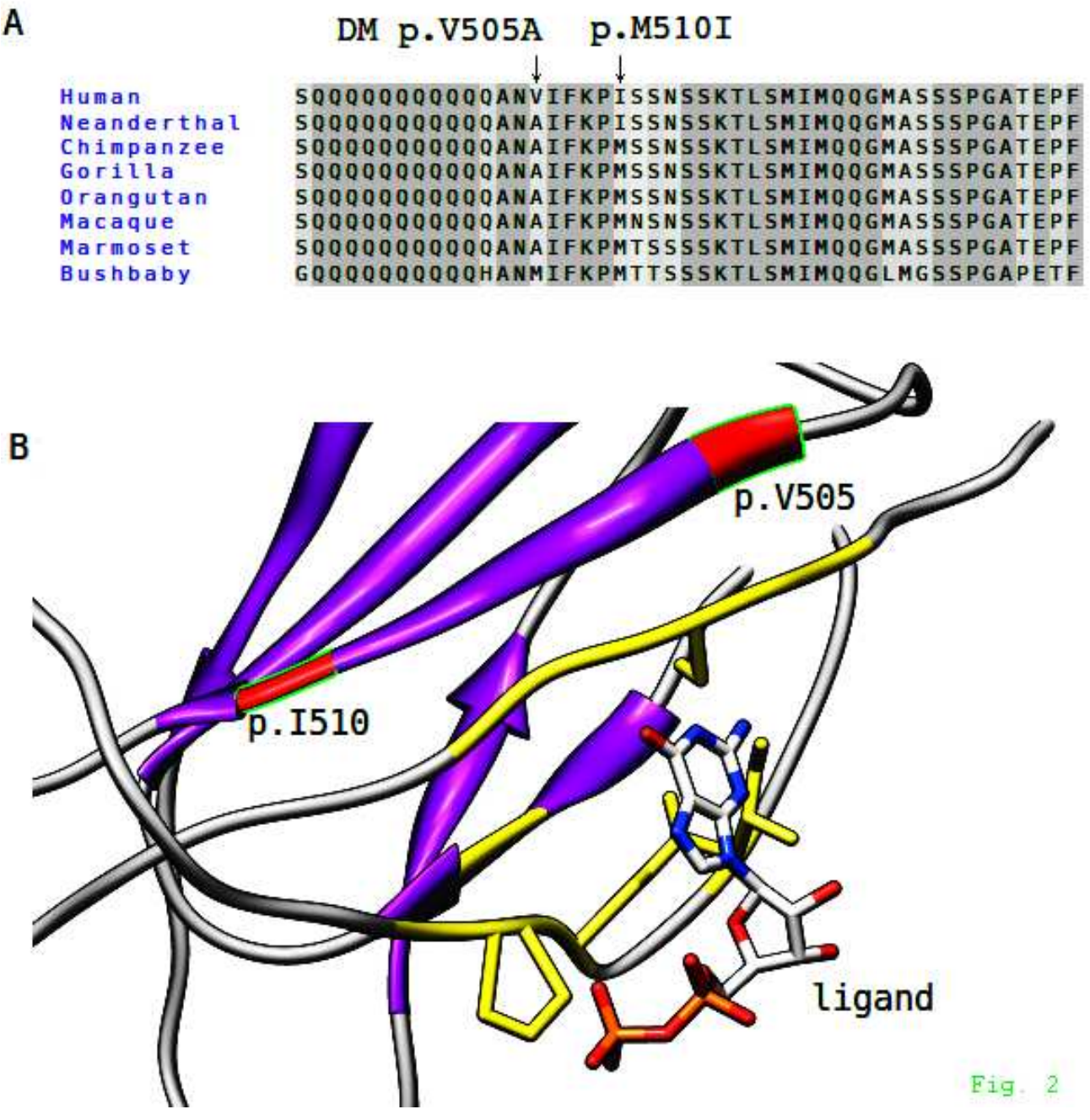

$49 \times 50 \mathrm{~mm}(300 \times 300 \mathrm{DPI})$

John Wiley \& Sons, Inc. 
A

Human

Neanderthal

Chimpanzee

Gorilla

Macaque

Marmoset

Bushbaby orangutan
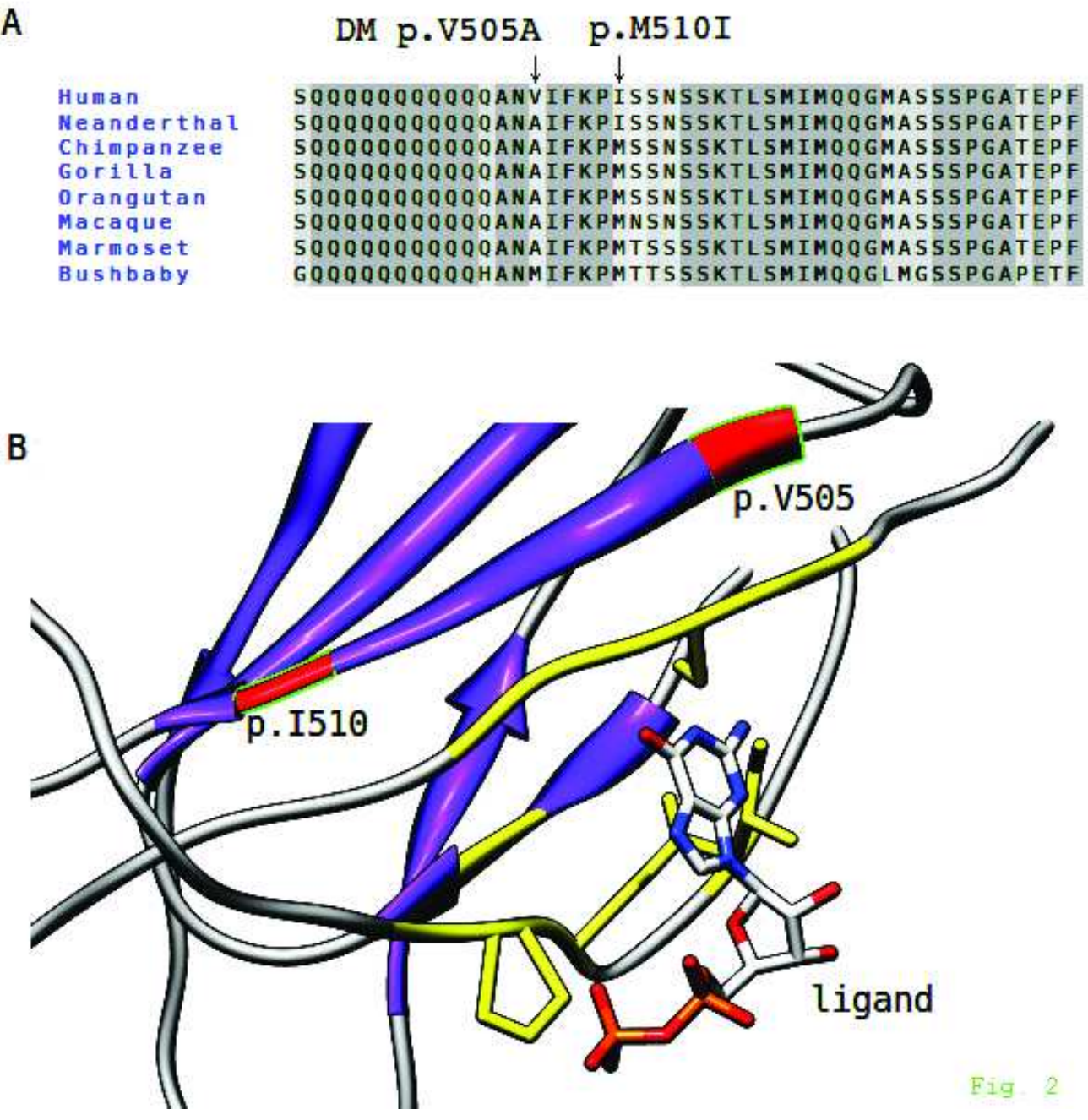

$49 \times 50 \mathrm{~mm}(300 \times 300$ DPI $)$

John Wiley \& Sons, Inc. 
Supp. Table S1. Potential compensated missense mutations in the Neanderthal and/or chimpanzee genome

\begin{tabular}{|c|c|c|c|c|c|c|c|c|c|c|c|}
\hline $\begin{array}{l}\text { HGMD } \\
\text { Acc. No. }\end{array}$ & $\begin{array}{l}\text { Chromosomal } \\
\text { location }\end{array}$ & Mutation & State & Tag & Human_disease_state & pmid & Gene & CpG & dbsnp id. & $\begin{array}{l}\text { HGVS (cDNA) } \\
\text { nomenclature }\end{array}$ & $\begin{array}{l}\text { HGVS (protein) } \\
\text { nomenclature }\end{array}$ \\
\hline CM067656 & chr1:156491643:+ & $\mathrm{C}=>\mathrm{G}: \mathrm{CG}$ & $\mathrm{D}$ & $\mathrm{DP}$ & $\begin{array}{l}\text { Guillain-Barre syndrome, reduced risk, } \\
\text { association with? } \\
\text { Psoriasis, increased risk, association }\end{array}$ & 16820217 & $C D 1 A$ & $\mathrm{~N}$ & rs2269715 & NM_001763.2:c.204C>G & NP_001754.2:p.C68W \\
\hline CM073141 & chr1:67457975:+ & $\mathrm{T}=>\mathrm{C}: \mathrm{CC}$ & A & DP & with & 17236132 & $I L 23 R$ & $\mathrm{~N}$ & rs7530511 & NM_144701.2:c.929T >C & NP_653302.2:p.L310P \\
\hline CM084632 & chr1:205366693:+ & $\mathrm{G}=>\mathrm{A}: \mathrm{GA}$ & $\mathrm{D}$ & DFP & $\begin{array}{l}\text { atypical, assoc. with } \\
\text { Breast cancer, reduced risk, association }\end{array}$ & 18424762 & C4BPA & Y & rs45574833 & NM_000715.3:c.719G>A & NP_000706.1:p.R240H \\
\hline CM100611 & chr1:12005513:+ & $\mathrm{A}=>\mathrm{G}: \mathrm{GG}$ & A & DFP & with & 20103646 & MIIP & $\mathrm{N}$ & rs2295283 & NM_021933.2:c.499A>G & NP_068752.2:p.K167E \\
\hline CM920010 & chr1:228912417:- & $\mathrm{T}=>\mathrm{C}: \mathrm{CC}$ & A & DP & Hypertension, association with & 1394429 & $A G T$ & $\mathrm{~N}$ & rs699 & NM_000029.2:c.803T>C & NP_000020.1:p.M268T \\
\hline CM980072 & chr1:21767322:+ & $\mathrm{T}=>\mathrm{C}: \mathrm{CC}$ & A & DFP & $\begin{array}{l}\text { Hypophosphatasia, association with } \\
\text { Tuberculosis, reduced susceptibility, }\end{array}$ & 9781036 & $A L P L$ & $\mathrm{~N}$ & rs3200254 & NM_000478.3:c.787T >C & NP_000469.3:p.Y263H \\
\hline СM066604 & chr2:230758959:- & $\mathrm{C}=>\mathrm{T}: \mathrm{TC}$ & $\mathrm{D}$ & $\mathrm{DP}$ & $\begin{array}{l}\text { association with } \\
\text { Higher body mass index, association }\end{array}$ & 16803959 & SP110 & $\mathrm{Y}$ & rs3948464 & NM_004509.2:c.1274C>T & NP_004500.2:p.S425L \\
\hline СМ073086 & chr2:85634047:- & $\mathrm{G}=>\mathrm{A}: \mathrm{GA}$ & $\mathrm{D}$ & $\mathrm{DP}$ & $\begin{array}{l}\text { with } \\
\text { Higher testosterone levels, association }\end{array}$ & 17029979 & GGCX & $\mathrm{Y}$ & rs699664 & NM_000821.3:c.974G>A & NP_000812.2:p.R325Q \\
\hline CM087379 & chr2:100957736:+ & $A=>G: G G$ & A & FP & $\begin{array}{l}\text { with } \\
\text { Nephropathy, reduced risk, association }\end{array}$ & 18990770 & NPAS2 & $\mathrm{N}$ & rs2305160 & $\begin{array}{l}\text { NM_002518.3:c.1180A>G } \\
\text { NM_001102416.1:c.533T> }\end{array}$ & NP_002509.2:p.T394A \\
\hline CM065290 & chr3:187925712:+ & $\mathrm{T}=>\mathrm{C}: \mathrm{CC}$ & A & $\mathrm{DP}$ & with & 17065357 & KNG1 & $\mathrm{N}$ & rs1656922 & $\mathrm{C}$ & NP_001095886.1:p.M178T \\
\hline СM066581 & chr3:126109714:- & $\mathrm{A}=>\mathrm{C}: \mathrm{CC}$ & A & $\mathrm{DP}$ & $\begin{array}{l}\text { Ulcerative colitis, association with } \\
\text { Periodontitis, aggressive, association }\end{array}$ & 17058067 & MUC13 & $\mathrm{N}$ & rs1127233 & NM_033049.2:c.1506A>C & NP_149038.2:p.R502S \\
\hline CM096382 & chr3:46476217:- & $A=>G: G G$ & A & DFP & with & 18973542 & $L T F$ & $\mathrm{~N}$ & rs1126478 & NM_002343.2:c.140A>G & NP_002334.2:p.K47R \\
\hline CM941277 & chr3:172214994:- & $\mathrm{C}=>\mathrm{T}: \mathrm{CT}$ & $\mathbf{D}$ & DP & Diabetes, NIDDM, association with & 8063045 & $S L C 2 A 2$ & $\mathbf{N}$ & rs5400 & NM_000340.1:c.329C >T & NP_000331.1:p.T110I \\
\hline CM031390 & chr4:141708518:- & $\mathbf{G}=>\mathbf{A}: \mathbf{A A}$ & A & DP & Waist-to-hip ratio, association with & 12756473 & UCP1 & $\mathbf{Y}$ & rs45539933 & NM_021833.3:c.190G>A & NP_068605.1:p.A64T \\
\hline СM094340 & chr4:38476105:- & $\mathrm{A}=>\mathrm{G}: \mathrm{GG}$ & A & DFP & Leprosy, association with & 19456232 & $T L R 1$ & $\mathrm{~N}$ & rs4833095 & NM_003263.3:c.743A>G & NP_003254.2:p.N248S \\
\hline CM060415 & chr6:150156438:+ & $A=>G: G A$ & $\mathrm{D}$ & FP & $\begin{array}{l}\text { Reduced stability, association with } \\
\text { Reduced metformin uptake, }\end{array}$ & 9343375 & PCMT1 & $\mathrm{N}$ & rs4816 & NM_005389.1:c.358A>G & NP_005380.1:p.I120V \\
\hline CM072043 & chr6:160462998:+ & $\mathrm{C}=>\mathrm{T}: \mathrm{CT}$ & $\mathrm{D}$ & FP & association with & 17476361 & SLC22A1 & $\mathrm{N}$ & rs34447885 & NM_003057.2:c.41C>T & NP_003048.1:p.S14F \\
\hline
\end{tabular}




\begin{tabular}{|c|c|c|c|c|c|c|c|c|c|c|c|}
\hline $\begin{array}{l}\text { HGMD } \\
\text { Acc. No. }\end{array}$ & $\begin{array}{l}\text { Chromosomal } \\
\text { location }\end{array}$ & Mutation & State & Tag & Human_disease_state & pmid & Gene & CpG & dbsnp id. & $\begin{array}{l}\text { HGVS (cDNA) } \\
\text { nomenclature }\end{array}$ & $\begin{array}{l}\text { HGVS (protein) } \\
\text { nomenclature }\end{array}$ \\
\hline CM074911 & chr6:39433056:- & $\mathrm{T}=>\mathrm{C}: \mathrm{CC}$ & A & DP & $\begin{array}{l}\text { Coronary heart disease, association } \\
\text { with }\end{array}$ & 18073581 & KIF6 & $\mathrm{N}$ & rs20455 & NM_145027.4:c.2155T>C & NP_659464.3:p.W719R \\
\hline CM993455 & chr6:132214061:+ & $A=>C: C C$ & A & DFP & $\begin{array}{l}\text { Insulin resistance/obesity, } \\
\text { association with }\end{array}$ & 10480624 & ENPP1 & $\mathbf{N}$ & rs1044498 & NM_006208.1:c.361A>C & NP_006199.1:p.K121Q \\
\hline CM031368 & chr7:141319814:- & $\mathrm{G}=>\mathrm{C}: \mathrm{CC}$ & A & DP & $\begin{array}{l}\text { Phenylthiocarbamide taste sensitivity, } \\
\text { association }\end{array}$ & 12595690 & TAS2R38 & $\mathrm{N}$ & rs713598 & NM_176817.2:c.145G>C & NP_789787.2:p.A49P \\
\hline СM031370 & chr7:141319073:- & $\mathrm{A}=>\mathrm{G}: \mathrm{GG}$ & A & $\mathrm{DP}$ & $\begin{array}{l}\text { association with } \\
\text { Inflammatory bowel disease, }\end{array}$ & 12595690 & TAS2R38 & $\mathrm{N}$ & rs10246939 & NM_176817.2:c.886A>G & NP_789787.2:p.I296V \\
\hline CM033585 & chr7:86998554:- & $\mathrm{T}=>\mathrm{G}: \mathrm{GG}$ & A & DP & association with & 14610718 & $A B C B 1$ & $\mathrm{~N}$ & rs2032582 & NM_000927.3:c.2677T>G & NP_000918.2:p.S893A \\
\hline CM930596 & chr7:94775382:- & $A=>G: G G$ & A & DFP & Longevity, association with & 15050299 & PON1 & $\mathbf{N}$ & rs662 & NM_000446.3:c.575A>G & NP_000437.3:p.Q192R \\
\hline CM024569 & chr8:18124476:+ & $\mathrm{T}=>\mathrm{G}: \mathrm{GG}$ & A & FP & Increased activity, association with & 12172214 & NAT1 & $\mathrm{N}$ & rs4986783 & NM_000662.4:c.640T>G & NP_000653.3:p.S214A \\
\hline СM081694 & chr8:6466450:+ & $\mathrm{C}=>\mathrm{T}: \mathrm{TT}$ & A & $\mathrm{DP}$ & $\begin{array}{l}\text { Cranial volume, association with } \\
\text { Gastric cancer, diffuse-type, }\end{array}$ & 18204051 & MCPH1 & $\mathrm{Y}$ & rs1057090 & NM_024596.2:c.2282C>T & NP_078872.2:p.A761V \\
\hline СM081761 & chr8:143758933:+ & $\mathrm{C}=>\mathrm{T}: \mathrm{TT}$ & A & DFP & association with & 18488030 & PSCA & $\mathrm{Y}$ & rs2294008 & NM_005672.3:c.2C>T & NP_005663.1:p.T1M \\
\hline CM099178 & chr8:118899878:- & $G=>A: G A$ & $\mathrm{D}$ & $\mathrm{DM}$ & Multiple osteochondromas & 19810120 & EXT1 & $\mathrm{Y}$ & & NM_000127.2:c.1609G>A & NP_000118.2:p.V537I \\
\hline CM950017 & chr8:37942955:- & $\mathrm{T}=>\mathrm{C}: \mathrm{CC}$ & A & DFP & Hyperinsulinaemia, association with & 7487991 & ADRB3 & $\mathrm{N}$ & rs4994 & NM_000025.1:c.190T>C & NP_000016.1:p.W64R \\
\hline CM940804 & chr9:34639442:+ & $A=>G: G G$ & A & DFP & $\begin{array}{l}\text { Galactosaemia, Duarte variant } \\
\text { Higher plasma HDL cholesterol, }\end{array}$ & 8198125 & GALT & $\mathrm{N}$ & rs2070074 & $\begin{array}{l}\text { NM_000155.2:c.940A>G } \\
\text { NM_005502.2:c.2649A> }\end{array}$ & NP_000146.2:p.N314D \\
\hline СM990005 & chr9:106626574:- & $A=>G: G G$ & A & FP & $\begin{array}{l}\text { association with } \\
\text { Lung cancer, susceptibility to, }\end{array}$ & 10431237 & ABCA1 & $\mathbf{N}$ & rs2066714 & G & NP_005493.2:p.I883M \\
\hline CM067461 & chr10:81691702:- & $\mathrm{A}=>\mathrm{G}: \mathrm{GG}$ & A & DP & $\begin{array}{l}\text { association with } \\
\text { Alzheimer disease, increased risk, }\end{array}$ & 16741161 & SFTPD & $\mathrm{N}$ & rs2243639 & NM_003019.4:c.538A>G & NP_003010.4:p.T180A \\
\hline CM074765 & chr10:67710331:- & $\mathrm{G}=>\mathrm{A}: \mathrm{GA}$ & $\mathrm{D}$ & DP & $\begin{array}{l}\text { association with? } \\
\text { Decreased enzyme activity, association }\end{array}$ & 17209133 & CTNNA3 & $\mathrm{N}$ & rs4548513 & NM_013266.1:c.1787G>A & NP_037398.1:p.S596N \\
\hline CM025891 & chr11:74585230:+ & $\mathrm{C}=>\mathrm{T}: \mathrm{TT}$ & A & FP & $\begin{array}{l}\text { with } \\
\text { Altered receptor function, association }\end{array}$ & 12130747 & SLCO2B1 & $\mathrm{N}$ & rs2306168 & NM_007256.2:c.1457C>T & NP_009187.1:p.S486F \\
\hline CM080415 & chr11:113308238:+ & $\mathrm{A}=>\mathrm{C}: \mathrm{CC}$ & A & FP & with & 18184810 & HTR3B & $\mathrm{N}$ & rs1176744 & NM_006028.3:c.386A>C & NP_006019.1:p.Y129S \\
\hline CM033453 & chr12:107542027:- & $\mathrm{G}=>\mathrm{A}: \mathrm{AA}$ & A & DFP & $\begin{array}{l}\text { Incident coronary heart disease, } \\
\text { decreased risk in African Americans, }\end{array}$ & 17420019 & SELPLG & $\mathrm{N}$ & rs2228315 & NM_003006.3:c.186G>A & NP_002997.1:p.M62I \\
\hline
\end{tabular}




\begin{tabular}{|c|c|c|c|c|c|c|c|c|c|c|c|}
\hline $\begin{array}{l}\text { HGMD } \\
\text { Acc. No. }\end{array}$ & $\begin{array}{l}\text { Chromosomal } \\
\text { location }\end{array}$ & Mutation & State & Tag & Human_disease_state & pmid & Gene & CpG & dbsnp id. & $\begin{array}{l}\text { HGVS (cDNA) } \\
\text { nomenclature }\end{array}$ & $\begin{array}{l}\text { HGVS (protein) } \\
\text { nomenclature }\end{array}$ \\
\hline & & & & & $\begin{array}{l}\text { association with } \\
\text { Schizophrenia in females, association }\end{array}$ & & & & & & \\
\hline СM085048 & chr12:78539038:- & $\mathrm{T}=>\mathrm{G}: \mathrm{GG}$ & A & $\mathrm{DP}$ & with & 18281137 & PAWR & $\mathrm{N}$ & & NM_002583.2:c.597T>G & NP_002574.2:p.I199M \\
\hline CM950862 & chr12:5473868:+ & $\mathrm{G}=>\mathrm{A}: \mathrm{GA}$ & $\mathrm{D}$ & $\mathrm{DP}$ & $\begin{array}{l}\text { Schizophrenia, severe, increased risk, } \\
\text { association with }\end{array}$ & 7733919 & NTF3 & $\mathrm{N}$ & rs1805149 & NM_002527.4:c.227G>A & NP_002518.1:p.G76E \\
\hline & & & & & Hypertension, reduced risk, association & & & & & & \\
\hline СM994637 & chr12:6327323:- & $A=>G: G G$ & A & DFP & with & 10523338 & SCNN1A & $\mathrm{N}$ & rs2228576 & NM_001038.4:c.1987A>G & NP_001029.1:p.T663A \\
\hline СM022034 & chr13:32526193:+ & $\mathrm{G}=>\mathrm{C}: \mathrm{GC}$ & $\mathrm{D}$ & DP & $\begin{array}{l}\text { Age-related phenotypes, association } \\
\text { with } \\
\text { Apoptosis, unable to induce, }\end{array}$ & 11792841 & $K L$ & $\mathrm{~N}$ & rs9527025 & NM_004795.2:c.1109G>C & NP_004786.2:p.C370S \\
\hline СM033777 & chr14:24170122:- & $\mathrm{T}=>\mathrm{C}: \mathrm{CC}$ & A & $\mathrm{DP}$ & association with & 12594335 & $G Z M B$ & $\mathrm{~N}$ & rs2236338 & NM_004131.3:c.739T>C & NP_004122.1:p.Y247H \\
\hline СM070246 & chr14:60993992:+ & $\mathrm{G}=>\mathrm{A}: \mathrm{AA}$ & A & DFP & $\begin{array}{l}\text { Cerebral infarction, association with } \\
\text { Lung cancer, susceptibility to, }\end{array}$ & 17206144 & $P R K C H$ & $\mathrm{~N}$ & rs2230500 & NM_006255.3:c.1120G>A & NP_006246.2:p.V374I \\
\hline CM067475 & chr15:41555066:- & $\mathrm{C}=>\mathrm{G}: \mathrm{GG}$ & A & DP & $\begin{array}{l}\text { association with } \\
\text { Lung cancer, susceptibility to, }\end{array}$ & 16741161 & ТР53ВР1 & $\mathrm{N}$ & rs560191 & NM_005657.1:c.1059C>G & NP_005648.1:p.D353E \\
\hline СM067476 & chr15:41511938:- & $\mathrm{A}=>\mathrm{C}: \mathrm{CC}$ & A & $\mathrm{DP}$ & association with & 16741161 & ТР53BP1 & $\mathrm{N}$ & rs2602141 & NM_005657.1:c.3406A>C & NP_005648.1:p.K1136Q \\
\hline CM085365 & chr15:43185730:- & $A=>G: G G$ & A & $\mathrm{DM}$ & Hypothyroidism & 18765513 & DUOX2 & $\mathrm{N}$ & & NM_014080.4:c.2033A>G & NP_054799.4:p.H678R \\
\hline CM983400 & chr16:27263704:+ & $A=>G: G G$ & A & DFP & $\begin{array}{l}\text { Asthma, atopic, association with } \\
\text { Cardiac disease, susceptibility to, }\end{array}$ & 9620765 & $I L 4 R$ & $\mathrm{~N}$ & rs1805010 & NM_000418.2:c.223A>G & NP_000409.1:p.I75V \\
\hline СМ030773 & chr17:19753133:- & $\mathrm{A}=>\mathrm{G}: \mathrm{GG}$ & A & $\mathrm{DP}$ & $\begin{array}{l}\text { association } \\
\text { Progressive supranuclear palsy, }\end{array}$ & 12646697 & AKAP10 & $\mathrm{N}$ & rs203462 & $\begin{array}{l}\text { NM_007202.2:c.1936A>G } \\
\text { NM_001007532.1:c.20A> }\end{array}$ & NP_009133.2:p.I646V \\
\hline CM032397 & chr17:41432502:+ & $\mathrm{A}=>\mathrm{G}: \mathrm{AG}$ & $\mathrm{D}$ & DP & $\begin{array}{l}\text { association with } \\
\text { Atherosclerotic stenosis, increased }\end{array}$ & 12913211 & STH & $\mathrm{N}$ & rs62063857 & G & NP_001007533.1:p.Q7R \\
\hline CM057933 & chr17:4585312:- & $\mathrm{C}=>\mathrm{T}: \mathrm{CT}$ & $\mathrm{D}$ & DP & $\begin{array}{l}\text { severity, association with } \\
\text { Breast cancer, ER negative, association }\end{array}$ & 15836657 & CXCL16 & $\mathrm{N}$ & rs2277680 & NM_022059.2:c.599C >T & NP_071342.2:p.A200V \\
\hline CM077855 & chr17:7532893:+ & $\mathrm{C}=>\mathrm{G}: \mathrm{GG}$ & A & DP & $\begin{array}{l}\text { with? } \\
\text { Increased sex hormone-binding }\end{array}$ & 17683073 & WRAP53 & $\mathrm{N}$ & rs2287499 & NM_018081.1:c.202C>G & NP_060551.1:p.R68G \\
\hline СM087381 & chr17:7987497:- & $\mathrm{G}=>\mathrm{C}: \mathrm{CC}$ & A & FP & $\begin{array}{l}\text { globulin levels, association with } \\
\text { Hip bone mineral density, association }\end{array}$ & 18990770 & PER1 & $\mathrm{N}$ & rs2585405 & NM_002616.1:c.2884G>C & NP_002607.1:p.A962P \\
\hline CM093418 & chr17:39581073:+ & $\mathrm{A}=>\mathrm{C}: \mathrm{CC}$ & A & $\mathrm{DP}$ & with? & 19079262 & C17orf53 & $\mathrm{N}$ & rs227584 & NM_024032.2:c.376A>C & NP_076937.2:p.T126P \\
\hline
\end{tabular}




\begin{tabular}{|c|c|c|c|c|c|c|c|c|c|c|c|}
\hline $\begin{array}{l}\text { HGMD } \\
\text { Acc. No. }\end{array}$ & $\begin{array}{l}\text { Chromosomal } \\
\text { location }\end{array}$ & Mutation & State & Tag & lisease_state & pmid & Gene & CpG & dbsnp id. & $\begin{array}{l}\text { HGVS (cDNA) } \\
\text { nomenclature }\end{array}$ & $\begin{array}{l}\text { HGVS (protein) } \\
\text { nomenclature }\end{array}$ \\
\hline & & & & & Basal cell carcinoma, reduced risk, & & & & & & \\
\hline M004814 & chr19:50546759:- & $\mathrm{A}=>\mathrm{C}: \mathrm{CC}$ & A & DFP & association with & 9950243 & ERCC2 & $\mathrm{N}$ & rs13181 & NM_000400.2:c.2251A>C & NP_000391.1:p.K751Q \\
\hline & & & & & Creutzfeldt-Jakob disease, as & & & & & & \\
\hline СM014824 & chr20:4653718:+ & $\mathrm{C}=>\mathrm{T}: \mathrm{TT}$ & A & DP & with & 11702213 & $P R N D$ & $\mathrm{Y}$ & rs2245220 & NM_012409.2:c.521C>T & NP_036541.2:p.T174M \\
\hline M025479 & :+ & G:GG & A & DP & $\begin{array}{l}\text { with } \\
\text { Multiple sclerosis, susceptibility to, }\end{array}$ & & & $\mathbf{N}$ & & & $278 \mathrm{R}$ \\
\hline CM057711 & chr21:33536125:+ & $\mathrm{T}=>\mathrm{G}: \mathrm{GG}$ & A & DP & association with & 15885318 & IFNAR2 & $\mathrm{N}$ & rs1051393 & NM_207585.1:c.28T>G & NP_997468.1:p.F10V \\
\hline CM057927 & chr22:21957369:+ & $\mathrm{A}=>\mathrm{G}: \mathrm{GG}$ & A & DP & $\begin{array}{l}\text { Bipolar disorder, association with? } \\
\text { Iron status and erythrocyte volume, }\end{array}$ & 15866548 & $B C R$ & $\mathrm{~N}$ & rs140504 & NM_004327.3:c.2387A>G & NP_004318.3:p.N796S \\
\hline M085353 & chrX:149390017:+ & $\mathrm{T}=>\mathrm{C}: \mathrm{CC}$ & A & DM & Hypospadias & 18635673 & MAMLD1 & $\mathrm{N}$ & & NM_005491.2:c.1514T>C & NP_005482.2:p.V505A \\
\hline
\end{tabular}

Mutation: human normal =>human mutation: Neanderthal genotype, chimpanzee genotype. HGMD: Human Gene Mutation Database. A: Ancestral, D: Derived. DM: disease-causing mutation; DFP: disease-associated functional polymorphism; DP: disease-associated polymorphism; FP: functional polymorphism. CpG column provides information as to whether the corresponding mutation occurred in a CpG dinucleotide in human and was either a $\mathrm{C}>\mathrm{T}$ or G>A transition compatible with methylation-mediated deamination of 5-methylcytosine (Y denotes yes, $\mathrm{N}$ denotes no). HGVS (cDNA) nomenclature provides cDNA numbering with +1 corresponding to the A of the ATG translational initiation codon in the corresponding reference sequence. HGVS (protein) nomenclature provides numbering with respect to the corresponding reference protein sequence, with the translational initiation codon being codon 1. Entries marked in bold type were previously identified as 'compensated mutations' by Mikkelsen et al. (2005). These are putative disease-causing/disease-associated variants in human that correspond to the wild-type in chimpanzee. 
Supp. Table S2. Potential compensated regulatory mutations in the Neanderthal and/or chimpanzee genome

\begin{tabular}{|c|c|c|c|c|c|c|c|c|c|}
\hline HGMD & Chromosomal & & & & & & & & \\
\hline Acc. No. & location & Mutation & State & Tag & Human_disease_state & pmid & Gene & CpG & dbsnp \\
\hline CR060579 & chr1:111020443:- & $A=>G: G A$ & $\mathrm{D}$ & DP & Low insulin sensitivity, association with & 16317062 & KCNA3 & $\mathrm{N}$ & rs2821557:A>G \\
\hline CR043164 & chr1:43575707:+ & $\mathrm{C}=>\mathrm{A}: \mathrm{AA}$ & A & DP & Platelet count, association with? & 15307100 & MPL & $\mathrm{N}$ & rs839993:C>A \\
\hline CR057791 & chr1:111571946:+ & $\mathrm{G}=>\mathrm{T}: \mathrm{TG}$ & $\mathrm{D}$ & FP & Increased promoter activity, association with & 16251966 & CHI3L2 & $\mathrm{N}$ & rs755467:G>T \\
\hline CR025943 & chr1:228917021:- & $\mathrm{C}=>\mathrm{T}: \mathrm{CT}$ & $\mathrm{D}$ & DP & Increased angiotensinogen levels, association with? & 12404103 & AGT & $\mathrm{N}$ & rs5046:C>T \\
\hline CR025220 & chr2:234330398:+ & $\mathrm{T}=>\mathrm{G}: \mathrm{GG}$ & A & DFP & Hyperbilirubinaemia, association with & 11906189 & UGT1A1 & $\mathrm{N}$ & rs4124874:T>G \\
\hline CR033690 & chr2:227372145:- & $\mathrm{G}=>\mathrm{A}: \mathrm{AA}$ & A & DP & Diabetes, NIDDM, association with & 14633864 & IRS1 & $\mathrm{N}$ & rs13306465:G>A \\
\hline CR086331 & chr2:234291987:+ & $\mathrm{C}=>\mathrm{T}: \mathrm{CT}$ & $\mathrm{D}$ & FP & Reduced expression, association with & 18433817 & UGT1A4 & $\mathrm{N}$ & rs3732219:C>T \\
\hline CR066664 & chr3:129680794:- & $\mathrm{C}=>\mathrm{T}: \mathrm{CT}$ & $\mathrm{D}$ & DP & Coronary artery disease, association with & 16934006 & GATA2 & $\mathrm{Y}$ & rs2713579:C>T \\
\hline CR032439 & chr3:12328198:+ & $\mathrm{C}=>\mathrm{G}: \mathrm{GG}$ & A & DFP & Increased height/lipid metabolism, association with & 12588773 & PPARG & $\mathrm{N}$ & rs10865710:C>G \\
\hline CR014438 & chr3:185572960:- & $\mathrm{G}=>\mathrm{A}: \mathrm{AA}$ & A & DP & Myocardial infarction, association with & 11257273 & ТНPO & $\mathrm{Y}$ & rs6141:G>A \\
\hline CR025435 & chr4:111053559:+ & $A=>G: G G$ & A & DFP & Malignant melanoma, association with & 11844511 & $E G F$ & $\mathrm{~N}$ & rs4444903:A>G \\
\hline CR004797 & chr4:26101320:- & $\mathrm{G}=>\mathrm{T}: \mathrm{GT}$ & $\mathrm{D}$ & DP & Higher percent body fat, association with & 10682840 & CCKAR & $\mathrm{N}$ & rs1800908:G>T \\
\hline CR045948 & chr4:69995928:+ & $\mathrm{G}=>\mathrm{A}: \mathrm{AA}$ & A & FP & Promoter activity, association with & 15001974 & UGT2B7 & $\mathrm{Y}$ & rs7438135:G>A \\
\hline CR071281 & chr4:156348632:+ & $\mathrm{C}=>\mathrm{T}: \mathrm{TT}$ & A & DP & Obesity, association with & 17235527 & $N P Y 2 R$ & $\mathrm{Y}$ & rs6857715:C>T \\
\hline CR035513 & chr5:131436741:+ & $\mathrm{A}=>\mathrm{C}: \mathrm{CC}$ & A & DP & Reduced severity in atopic dermatitis, association with & 13679820 & CSF2 & $\mathrm{N}$ & rs4124874:T>G \\
\hline CR057231 & chr5:71047268:+ & $\mathrm{T}=>\mathrm{C}: \mathrm{CC}$ & A & DP & Obesity, association with? & 15823203 & CARTPT & $\mathrm{N}$ & rs4703647:T>C \\
\hline CR071289 & chr5:1499389:- & $\mathrm{T}=>\mathrm{C}: \mathrm{CC}$ & A & DP & Attention-deficit hyperactivity disorder, association with & 17044101 & SLC6A3 & $\mathrm{N}$ & rs2652511:T>C \\
\hline CR052970 & chr6:132254387:+ & $A=>G: G G$ & A & DP & Obesity, association with & 16025115 & ENPP1 & $\mathrm{N}$ & rs7754561:A>G \\
\hline CR082018 & chr6:78227843:- & $\mathrm{G}=>\mathrm{A}: \mathrm{GA}$ & $\mathrm{D}$ & DFP & Aggressive behaviour, association with & 18283276 & HTR1B & Y & rs13212041:G>A \\
\hline CR077383 & chr6:154401054:+ & $A=>G: G G$ & A & FP & Increased promoter activity, association with & 16843022 & OPRM1 & $\mathrm{N}$ & rs17174629:A>G \\
\hline CR075274 & chr6:133077018:- & $\mathrm{T}=>\mathrm{G}: \mathrm{GG}$ & A & DP & HDL cholesterol concentration, association with & 17873875 & $V N N 1$ & $\mathrm{~N}$ & rs4897612:T>G \\
\hline CR075243 & chr6:132314950:- & $\mathrm{G}=>\mathrm{C}: \mathrm{CG}$ & $\mathrm{D}$ & DFP & Systemic sclerosis, association with & 17881752 & CTGF & $\mathrm{N}$ & rs6918698:G>C \\
\hline CR073540 & chr6:131935252:+ & $\mathrm{G}=>\mathrm{T}: \mathrm{TT}$ & A & DP & Myocardial infarction, association with & 17369504 & ARG1 & $\mathrm{N}$ & rs2781666:G>T \\
\hline CR012231 & chr6:32260420:- & $\mathrm{T}=>\mathrm{C}: \mathrm{CC}$ & A & DFP & Diabetic retinopathy, association with & 11375354 & AGER & $\mathrm{N}$ & rs1800625:T>C \\
\hline CR092300 & chr7:111902894:+ & $\mathrm{C}=>\mathrm{T}: \mathrm{TT}$ & A & DFP & Severity in cystic fibrosis, association with & 19242412 & IFRD1 & $\mathrm{N}$ & rs7817:C>T \\
\hline CR068449 & chr7:128381961:+ & $\mathrm{C}=>\mathrm{T}: \mathrm{TT}$ & A & DP & Systemic lupus erythematosus, association with? & 16642019 & IRF5 & Y & rs2280714:C>T \\
\hline CR066667 & chr7:30969948:+ & $\mathrm{C}=>\mathrm{T}: \mathrm{TT}$ & A & DP & Breast cancer, decreased risk, association with & 16606630 & GHRHR & $\mathrm{Y}$ & rs2302019:C>T \\
\hline CR971950 & chr8:19840951:+ & $\mathrm{T}=>\mathrm{G}: \mathrm{GG}$ & A & FP & Lower plasma triglyceride level, association with & 9017514 & $L P L$ & $\mathrm{~N}$ & rs1800590:T>G \\
\hline
\end{tabular}




\begin{tabular}{|c|c|c|c|c|c|}
\hline HGMD & Chromosomal & & & & \\
\hline Acc. No. & location & Mutation & State & Tag & Human_disease_state \\
\hline CR034594 & chr9:124172343:+ & $A=>G: G G$ & A & FP & Inhibition of prostaglandin $\mathrm{H} 2$ formation, association with? \\
\hline CR102176 & chr9:100952292:+ & $\mathrm{A}=>\mathrm{G}: \mathrm{GG}$ & A & DFP & Breast cancer, association with \\
\hline CR091269 & chr9:116608587:- & $\mathrm{T}=>\mathrm{C}: \mathrm{CC}$ & A & DFP & Crohn's disease, susceptibility to, association with \\
\hline CR054255 & chr9:127043845:- & $A=>G: G G$ & A & DP & Bipolar disorder, association with? \\
\hline CR045560 & chr9:106730659:- & $\mathrm{G}=>\mathrm{C}: \mathrm{CC}$ & A & FP & Reduced plasma HDL cholesterol, association with \\
\hline CR072313 & chr10:94452862:+ & $\mathrm{C}=>\mathrm{T}: \mathrm{CT}$ & $\mathrm{D}$ & DP & Diabetes, type 2 , association with? \\
\hline CR942079 & chr10:104587142:- & $\mathrm{T}=>\mathrm{C}: \mathrm{CC}$ & A & DP & Polycystic ovaries, association with \\
\hline CR102882 & chr10:64279946:- & $\mathrm{G}=>\mathrm{A}: \mathrm{GA}$ & $\mathrm{D}$ & DFP & Systemic lupus erythematosus, association with \\
\hline CR094845 & chr11:74539529:+ & $\mathrm{G}=>\mathrm{A}: \mathrm{AA}$ & A & FP & Increased mRNA expression, association with \\
\hline CR096333 & chr11:85546288:- & $\mathrm{A}=>\mathrm{G}: \mathrm{GG}$ & A & DP & Alzheimer disease, association with? \\
\hline CR035965 & chr11:45863406:+ & $\mathrm{A}=>\mathrm{G}: \mathrm{GG}$ & A & DFP & Alzheimer disease, association with \\
\hline CR025510 & chr11:102331749:- & $\mathrm{G}=>\mathrm{A}: \mathrm{GA}$ & $\mathrm{D}$ & FP & Increased transcriptional activity, association with \\
\hline CR082031 & chr12:55796928:- & $G=>A: A A$ & A & DP & Schistosomiasis infection, association with \\
\hline CR031478 & chr12:10203556:- & $\mathrm{C}=>\mathrm{T}: \mathrm{CT}$ & $\mathrm{D}$ & DP & Alzheimer disease, reduced risk, association with \\
\hline CR080758 & chr13:45577313:- & $\mathrm{A}=>\mathrm{G}: \mathrm{AG}$ & $\mathrm{D}$ & FP & Increased promoter activity, association with \\
\hline CR994765 & chr13:112807756:+ & $\mathrm{G}=>\mathrm{T}: \mathrm{TC}$ & $\mathrm{N}$ & DFP & Reduced plasma F7 levels, association with \\
\hline CR045986 & chr14:51803734:+ & $\mathrm{T}=>\mathrm{C}: \mathrm{CC}$ & A & DFP & Asthma, association with \\
\hline CR993820 & chr15:72828970:+ & $C=>A: A A$ & A & DFP & Increased activity in smokers, association with \\
\hline CR066661 & chr15:49336891:- & $\mathrm{C}=>\mathrm{T}: \mathrm{TT}$ & A & DP & Alzheimer's, in APOE4 carriers, increased risk, association with \\
\hline CR002154 & chr15:56511231:+ & $\mathrm{G}=>\mathrm{A}: \mathrm{GA}$ & $\mathrm{D}$ & DP & Dyslipidaemia and insulin resistance, association \\
\hline CR994768 & chr17:41327398:+ & $\mathrm{G}=>\mathrm{C}: \mathrm{CG}$ & D & DP & Supranuclear palsy, progressive, association with \\
\hline CR084012 & chr17:25549137:- & $\mathrm{T}=>\mathrm{G}: \mathrm{GG}$ & A & FP & Increased expression, association with \\
\hline CR052976 & chr17:43163827:+ & $\mathrm{T}=>\mathrm{C}: \mathrm{CC}$ & A & DP & Asthma, aspirin-induced, association with \\
\hline CR078280 & chr17:35323475:- & $\mathrm{G}=>\mathrm{A}: \mathrm{GA}$ & D & DP & Asthma, increased risk, association with? \\
\hline CR090198 & chr17:38531642:- & $\mathrm{A}=>\mathrm{G}: \mathrm{GG}$ & A & FP & Promoter activity, association with \\
\hline CR010588 & chr19:60077416:+ & $\mathrm{T}=>\mathrm{C}: \mathrm{CC}$ & A & DP & IgA nephropathy, association with \\
\hline CR051707 & chr19:7718733:- & $\mathrm{T}=>\mathrm{C}: \mathrm{CC}$ & A & DFP & Dengue disease, prot. against, association with \\
\hline CR050427 & chr19:46188969:+ & $\mathrm{T}=>\mathrm{C}: \mathrm{CC}$ & A & FP & CYP2B6 expression, association with \\
\hline CR075263 & chr20:17370063:+ & $\mathrm{T}=>\mathrm{C}: \mathrm{CC}$ & A & DP & Diabetes, type 2 , association with \\
\hline R054260 & chr21:38590628:+ & $\mathrm{T}=>\mathrm{G}: \mathrm{TG}$ & $\mathrm{D}$ & FP & Promoter activity, association with \\
\hline
\end{tabular}

\begin{tabular}{|c|c|c|c|}
\hline pmid & Gene & CpG & dbsnp \\
\hline 12545150 & PTGS1 & $\mathrm{N}$ & rs10306114:A>G \\
\hline 20332227 & TGFBR1 & $\mathrm{N}$ & rs334348:A>G \\
\hline 19124533 & TNFSF15 & $\mathrm{N}$ & rs6478109:T>C \\
\hline 16168956 & HSPA5 & $\mathrm{N}$ & rs391957:A>G \\
\hline 15262183 & ABCA1 & $\mathrm{N}$ & rs2246293:G>C \\
\hline 17293876 & HHEX & $\mathrm{N}$ & rs1111875:C>T \\
\hline 7849715 & СYР17A1 & $\mathrm{N}$ & rs743572:T>C \\
\hline 20194224 & EGR2 & $\mathrm{N}$ & rs1412554:G>A \\
\hline 19620935 & SLCO2B1 & $\mathrm{N}$ & rs2712807:G>A \\
\hline 19734902 & PICALM & $\mathrm{N}$ & rs3851179:A>G \\
\hline 12740599 & МАРК8IP1 & $\mathrm{N}$ & rs1554338:A>G \\
\hline 12392760 & MMP13 & $\mathrm{N}$ & rs2252070:G>A \\
\hline 18273035 & STAT6 & $\mathrm{N}$ & rs324013:G>A \\
\hline 12807963 & OLR1 & $\mathrm{N}$ & rs1050283:C>T \\
\hline 17855631 & СРВ2 & $\mathrm{N}$ & rs11574980:A>G \\
\hline 10233895 & $F 7$ & $\mathrm{~N}$ & Rs510335:G>T \\
\hline 15496624 & $P T G D R$ & $\mathrm{~N}$ & rs8004654:T>C \\
\hline 10233211 & СYР1A2 & $\mathrm{N}$ & rs762551:C>A \\
\hline 16882736 & СУР19A1 & $\mathrm{Y}$ & rs1008805:C $>T$ \\
\hline 10894818 & LIPC & $\mathrm{N}$ & rs2070895:G>A \\
\hline 10580705 & MAPT & $\mathrm{N}$ & rs62056778:G>C \\
\hline 18445138 & SLC6A4 & $\mathrm{N}$ & rs1042173:T>G \\
\hline 15806396 & TBX21 & $\mathrm{N}$ & rs4794067:T>C \\
\hline 17611496 & GSDMB & $\mathrm{Y}$ & rs7216389:G>A \\
\hline 18782836 & BRCA1 & $\mathrm{N}$ & rs799906:A>G \\
\hline 11281451 & FCAR & $\mathrm{N}$ & rs3816051:T>C \\
\hline 15838506 & CD209 & $\mathrm{N}$ & rs4804803:T>C \\
\hline 15722458 & СУР2В6 & $\mathrm{N}$ & rs34223104:T>C \\
\hline 17618154 & PCSK2 & $\mathrm{N}$ & rs2021785:T>C \\
\hline 160 & KCNJ15 & $\mathrm{N}$ & rs2236606:T>G \\
\hline
\end{tabular}




\section{Page 49 of 49}

Human Mutation

Zhang et al., Human Mutation

HGMD Chromosomal

Acc. No. location

Mutation

State Tag

Human_disease_state

pmid

Gene

CpG

dbsnp

CR063398 chrX:135554616:+ A=>G:GG

A FP Increased soluble CD40L levels, association with

16627810

CD4OLG

$\mathrm{N}$

rs3092952:A>G

CR077381 chrX:113724838:+ G=>C:GC

FP Reduced promoter activity, association with

17376412

HTR2C

rs518147:G>C

Mutation: human normal =>human mutation: Neanderthal genotype, chimpanzee genotype. HGMD: Human Gene Mutation Database. A: Ancestral, D: Derived. DM: disease-causing mutation; DFP: disease-associated functional polymorphism; DP: disease-associated polymorphism; FP: functional polymorphism. CpG column provides information as to whether the corresponding (human) mutation occurred in a CpG dinucleotide and was either a $\mathrm{C}>\mathrm{T}$ or $\mathrm{G}>$ A transition compatible with methylation-mediated deamination of 5-methylcytosine (Y denotes yes, N denotes no). The dbSNP column refers to the dbSNP identifier and base change (dbSNP:wildtype>mutant). 